Prepared in cooperation with the U.S. Army Corps of Engineers and the Bureau of Reclamation

Social Attraction Used to Establish Caspian Tern (Hydroprogne caspia) Nesting Colonies on Modified Islands at the Don Edwards San Francisco Bay National Wildlife Refuge, California-Final Report

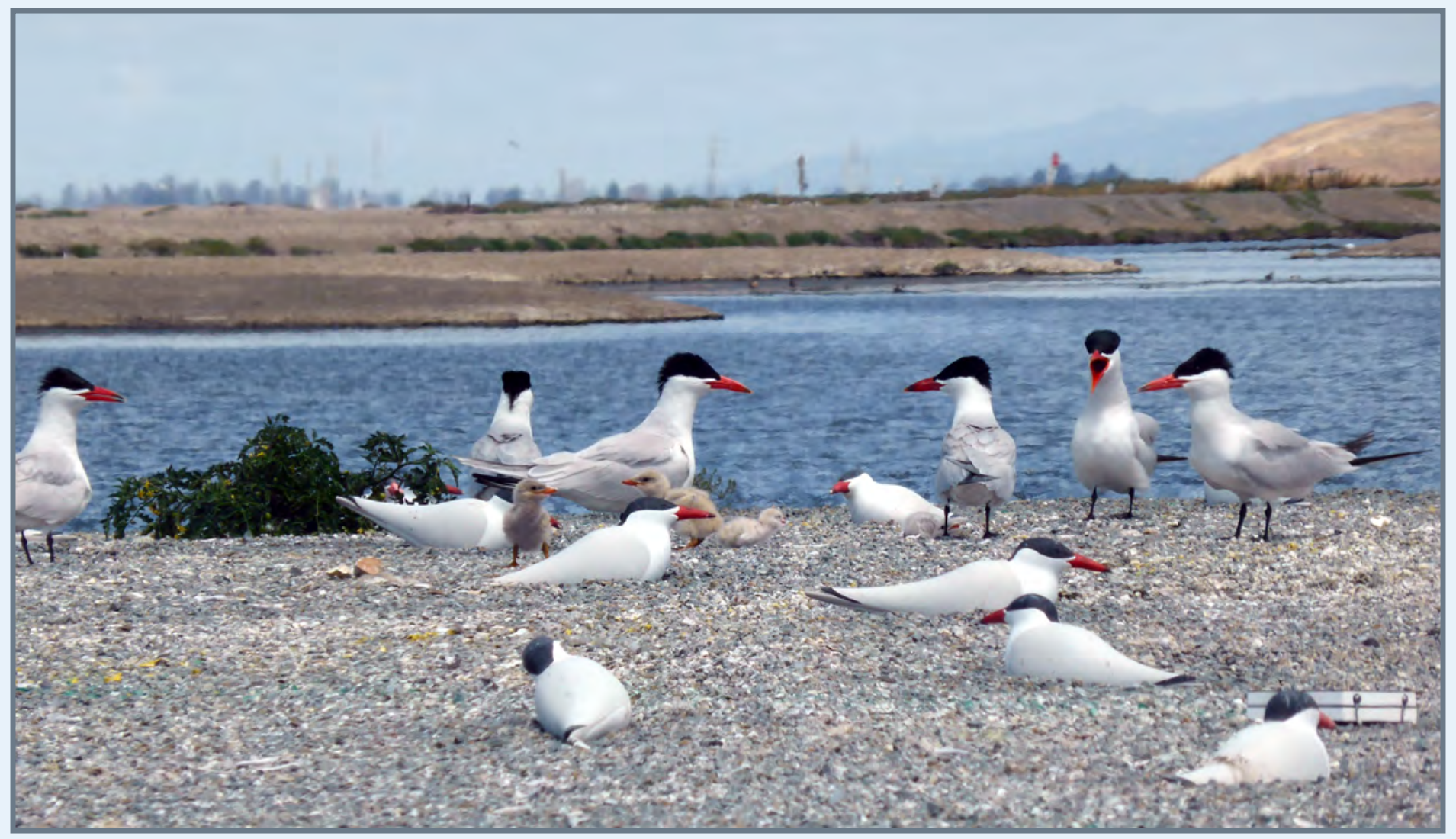

Open-File Report 2018-1136 
Cover: Photograph showing Caspian terns (Hydroprogne caspia) on Island 11 in Pond A16, Don Edwards San Francisco Bay National Wildlife Refuge,

California. Photograph by Crystal Shore, U.S. Geological Survey, May 23, 2016. 


\section{Social Attraction Used to Establish Caspian Tern (Hydroprogne caspia) Nesting Colonies on Modified Islands at the Don Edwards San Francisco Bay National Wildlife Refuge, California-Final Report}

By C. Alex Hartman, Joshua T. Ackerman, Mark P. Herzog, Cheryl Strong, David Trachtenbarg, and Crystal A. Shore

Prepared in cooperation with the U.S. Army Corps of Engineers and the Bureau of Reclamation

Open-File Report 2018-1136

U.S. Department of the Interior U.S. Geological Survey 


\section{U.S. Department of the Interior \\ RYAN K. ZINKE, Secretary}

\section{U.S. Geological Survey James F. Reilly II, Director}

U.S. Geological Survey, Reston, Virginia: 2018

For more information on the USGS—-the Federal source for science about the Earth, its natural and living resources, natural hazards, and the environment-visit https://www.usgs.gov/ or call 1-888-ASK-USGS (1-888-275-8747).

For an overview of USGS information products, including maps, imagery, and publications, visit https:/store.usgs.gov.

The findings and conclusions in this report are those of the authors and do not necessarily represent the views of the U.S. Fish and Wildlife Service.

Any use of trade, firm, or product names is for descriptive purposes only and does not imply endorsement by the U.S. Government.

Although this information product, for the most part, is in the public domain, it also may contain copyrighted materials as noted in the text. Permission to reproduce copyrighted items must be secured from the copyright owner.

Suggested citation:

Hartman, C.A., Ackerman, J.T., Herzog, M.P., Strong, C., Trachtenbarg, D., and Shore, C.A., 2018, Social attraction used to establish Caspian tern (Hydroprogne caspia) nesting colonies on modified islands at the Don Edwards San Francisco Bay National Wildlife Refuge, California-Final report: U.S. Geological Survey Open-File Report 2018-1136, 41 p., https://doi.org/10.3133/ofr20181136.

ISSN 2331-1258 (online) 


\section{Contents}

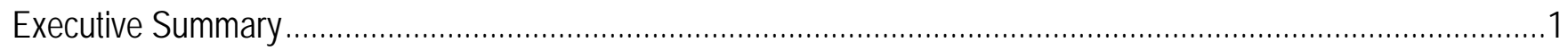

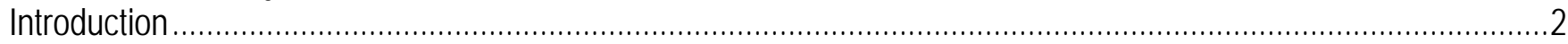

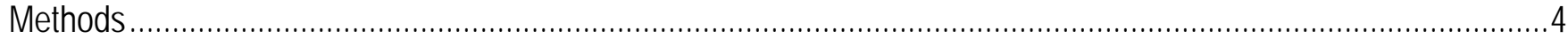

Social Attraction Measures for Caspian Terns and Snowy Plovers ............................................................. 4

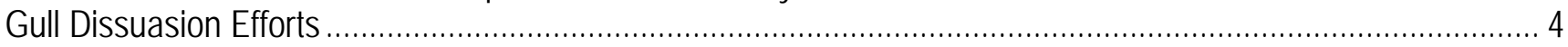

Evaluation of Nesting by Caspian Terns and Snowy Plovers .................................................................... 5

Estimating Colony Size and Productivity of Caspian Terns ....................................................................... 5

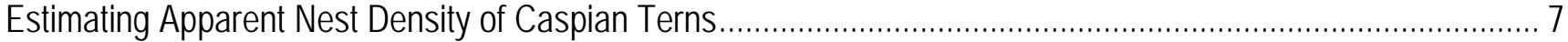

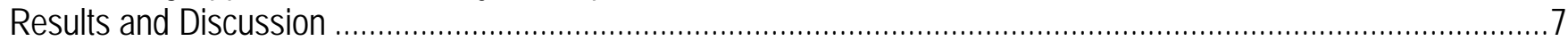

Abundance of Caspian Terns and Other Prominent Nesting Species in Ponds A16 and SF2 …...................... 7

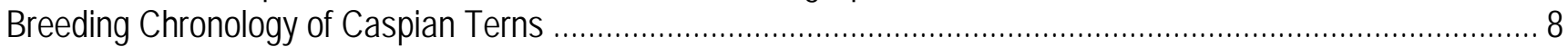

Size, Productivity, and Growth of Caspian Tern Breeding Colonies .............................................................. 8

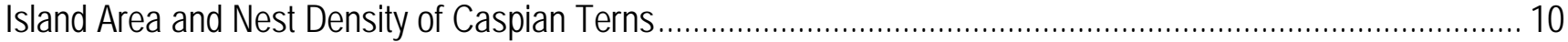

Sightings of Color-Banded Caspian Terns ................................................................................................. 11

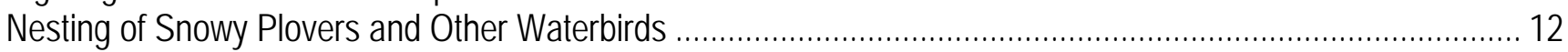

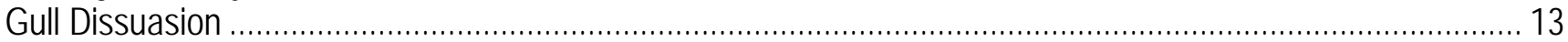

Factors Influencing Overall Success of Caspian Tern Colonies ................................................................. 13

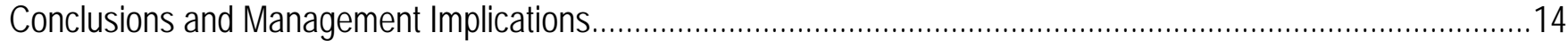

Acknowledgments.

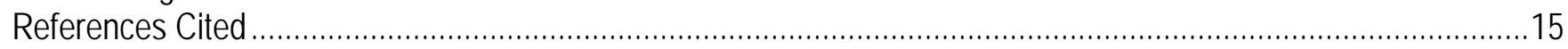

\section{Figures}

Figure 1. Locations of Ponds A16 and SF2 containing islands modified for Caspian terns and snowy plovers, Don Edwards San Francisco Bay National Wildlife Refuge, California ............................................................... 17

Figure 2. Locations of islands modified for nesting Caspian terns and nesting snowy plovers in Pond A16, Don Edwards San Francisco Bay National Wildlife Refuge, California ............................................................... 18

Figure 3. Locations of islands modified for nesting Caspian terns and nesting snowy plovers in Pond SF2, Don Edwards San Francisco Bay National Wildlife Refuge, California ............................................................. 19

Figure 4. Arrangement of social attraction measures for Caspian terns on modified Island 11 and Islands 11 and 12 in Pond A16, Don Edwards San Francisco Bay National Wildlife Refuge, California.

Figure 5. Arrangement of social attraction measures for Caspian terns on modified Island 12 and Island 17 in Pond SF2, Don Edwards San Francisco Bay National Wildlife Refuge, California.

Figure 6. Arrangement of social attraction measures for Caspian terns on modified Island 21 in Pond SF2, Don Edwards San Francisco Bay National Wildlife Refuge, California

Figure 7. Arrangement of social attraction measures for snowy plovers on modified Island 10 in Pond SF2, Don Edwards San Francisco Bay National Wildlife Refuge, California

Figure 8. Number of Caspian tern adults, incubating adults, chicks, fledglings, and active nests by date at Pond A16, Island 11; and Pond SF2, Island 21, Don Edwards San Francisco Bay National Wildlife Refuge, California, March-September 2015-17

Figure 9. Number of Caspian tern nests and fledglings by date on Island 11 in Pond A16 and Island 21 in Pond SF2 in 2015, 2016, and 2017, Don Edwards San Francisco Bay National Wildlife Refuge, California. 
Figure 10. Weekly high counts of individuals of the most abundant nesting waterbird species (excluding California gulls) observed during pond surveys at Ponds A16 and SF2, Don Edwards San Francisco Bay National Wildlife Refuge, California, March-September 2015-17....

Figure 11. Counts of Caspian terns, American avocets, black-necked stilts, California gulls, Forster's terns, and western snowy plovers at Pond A16, Don Edwards San Francisco Bay National Wildlife Refuge, California, during May-June of 2015-17

Figure 12. Counts of Caspian terns, American avocets, black-necked stilts, California gulls, Forster's terns, and western snowy plovers at Pond SF2, Don Edwards San Francisco Bay National Wildlife Refuge, California, during May-June of 2015-17

Figure 13. Percentage of Caspian tern observations by location during 166 behavior surveys conducted at Ponds A16 and SF2, Don Edwards San Francisco Bay National Wildlife Refuge, California, March-September 2015-17

Figure 14. Breeding chronology of Caspian terns based on observed behaviors at Ponds A16 and SF2, Don Edwards San Francisco Bay National Wildlife Refuge, California, in 2015, 2016, and 2017. 30

Figure 15. Aerial photograph showing Island 11 modified for Caspian terns in Pond A16, Don Edwards San Francisco Bay National Wildlife Refuge, California.

Figure 16. Aerial photograph showing Island 21 modified for Caspian terns in Pond SF2, Don Edwards San Francisco Bay National Wildlife Refuge, California.....

Figure 17. Total number of Caspian tern breeding pairs and fledglings, and the apparent breeding success and apparent nest density at Ponds A16 and SF2, and overall, Don Edwards San Francisco Bay National Wildlife Refuge, California, 2015-17

\section{Tables}

Table 1. Summary of social attraction efforts at three islands in Pond A16 and four islands in Pond SF2, Don Edwards San Francisco Bay National Wildlife Refuge, California, 2015-17

Table 2. Total number of Caspian terns observed and the number of surveys in which Caspian terns were observed on each island during 166 pond surveys conducted at Ponds A16 and SF2, Don Edwards San Francisco Bay National Wildlife Refuge, California, March-September 2015-17....

Table 3. Breeding metrics on seven modified islands with social attraction measures for Caspian terns and snowy plovers in Ponds A16 and SF2, Don Edwards San Francisco Bay National Wildlife Refuge, California, 2015-17 36

Table 4. Sightings of 52 color-banded Caspian terns at Ponds A16 and SF2, Don Edwards San Francisco Bay National Wildlife Refuge, California, 2015-17. 


\section{Conversion Factors}

U.S. customary units to International System of Units

\begin{tabular}{|c|c|c|}
\hline Multiply & By & To obtain \\
\hline \multicolumn{3}{|c|}{ Length } \\
\hline inch (in.) & 2.54 & \multirow{2}{*}{$\begin{array}{l}\text { centimeter }(\mathrm{cm}) \\
\text { meter }(\mathrm{m})\end{array}$} \\
\hline foot (ft) & 0.3048 & \\
\hline \multicolumn{3}{|c|}{ International System of Units to U.S. customary units } \\
\hline Multiply & By & To obtain \\
\hline \multicolumn{3}{|c|}{ Length } \\
\hline meter (m) & 3.281 & foot $(\mathrm{ft})$ \\
\hline kilometer (km) & 0.6214 & mile (mi) \\
\hline meter $(\mathrm{m})$ & 1.094 & yard (yd) \\
\hline \multicolumn{3}{|c|}{ Area } \\
\hline square meter $\left(\mathrm{m}^{2}\right)$ & 0.0002471 & acre \\
\hline square meter $\left(\mathrm{m}^{2}\right)$ & 10.76 & square foot $\left(\mathrm{ft}^{2}\right)$ \\
\hline
\end{tabular}

\section{Abbreviations}

$\begin{array}{ll}\text { BiOp } & \text { Biological Opinion } \\ \text { DENWR } & \text { Don Edwards San Francisco Bay National Wildlife Refuge } \\ \text { RPAs } & \text { Reasonable and Prudent Alternatives } \\ \text { RTK } & \text { Real-Time Kinematics } \\ \text { SBSP } & \text { South Bay Salt Pond } \\ \text { USACE } & \text { U.S. Army Corps of Engineers } \\ \text { USDA-APHIS } & \text { U.S. Department of Agriculture Animal and Plant Health Inspection Service } \\ \text { USGS } & \text { U.S. Geological Survey }\end{array}$


This page intentionally left blank. 


\section{Social Attraction Used to Establish Caspian Tern (Hydroprogne caspia) Nesting Colonies on Modified Islands at the Don Edwards San Francisco Bay National Wildlife Refuge, California-Final Report}

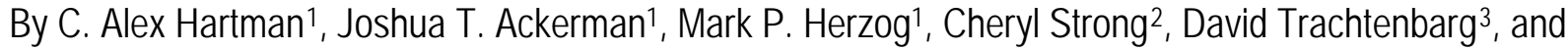
Crystal A. Shore ${ }^{1}$

\section{Executive Summary}

To address the 2008/2010 and Supplemental 2014 National Oceanic and Atmospheric Administration Fisheries Biological Opinion for operation of the Federal Columbia River Power System, the U.S. Army Corps of Engineers (USACE) and the Bureau of Reclamation (Reclamation) developed and began implementation of Caspian tern (Hydroprogne caspia) management plans. This implementation includes redistribution of the Caspian terns in the Columbia River estuary and the midColumbia River region to reduce predation on salmonids listed under the Endangered Species Act. Key elements of the plans are (1) reduction of nesting habitat for Caspian terns in the Columbia River estuary and the mid-Columbia River region, and (2) creation or modification of nesting habitat at alternative sites within the Caspian tern breeding range. As part of this effort, USACE and Reclamation developed Caspian tern nesting habitat at the U.S. Fish and Wildlife Service Don Edwards San Francisco Bay National Wildlife Refuge (DENWR), California, prior to the 2015 nesting season. Furthermore, nesting habitat for western snowy plovers (Charadrius alexandrinus nivosus) also was developed to provide separate nesting opportunities in the same managed ponds to reduce potential conflicts with Caspian terns. Specifically, seven recently constructed islands within two managed ponds (Ponds A16 and SF2) of DENWR were modified to provide habitat attractive to nesting Caspian terns (5 islands) and snowy plovers (2 islands). These 7 islands were a subset of 46 islands recently constructed in Ponds A16 and SF2 to provide waterbird nesting habitat as part of the South Bay Salt Pond (SBSP) Restoration Project.

\footnotetext{
${ }^{1}$ U.S. Geological Survey.

${ }^{2}$ U.S. Fish and Wildlife Service.

${ }^{3}$ U.S. Army Corps of Engineers.
} 
We used social attraction methods (decoys and electronic call systems) to attract Caspian terns and snowy plovers to these seven modified islands, and conducted surveys from March to September of 2015, 2016, and 2017 to evaluate nest numbers, nest density, and productivity. Results from the 2015 nesting season, the first year of the study, indicated that island modifications and social attraction measures were successful in establishing Caspian tern breeding colonies at Ponds A16 and SF2 of DENWR. Prior to 2015, there was no history of Caspian terns nesting in either Pond A16 or Pond SF2. The success of 2015 continued in 2016 and 2017. In 2017, the third and final year of the project, Caspian terns initiated at least 664 nests, fledged at least 239 chicks, and had a breeding success rate of 0.36 fledged chicks per breeding pair. This represents a 171 percent increase in the number of breeding pairs and a 41 percent increase in the number of chicks fledged, but a 48 percent decrease in the fledglings produced per breeding pair in 2017 compared to 2015, the first year the colonies were established. The two new large and growing Caspian tern nesting colonies at Ponds A16 and SF2 demonstrate the effectiveness of social attraction measures in helping to establish tern nesting colonies in San Francisco Bay. Social attraction measures similar to those used in this study, but targeting other colonial species such as Forster's terns (Sterna forsteri) and American avocets (Recurvirostra americana), may help to establish waterbird breeding colonies at wetlands enhanced as part of the SBSP Restoration Project.

\section{Introduction}

The U.S. Army Corps of Engineers (USACE), Walla Walla and Portland Districts, and the Bureau of Reclamation (Reclamation) (Action Agencies) are in the process of addressing the 2008/2010 and 2014 Supplemental National Oceanic and Atmospheric Administration Fisheries Biological Opinion (BiOp) for operation of the Federal Columbia River Power System that includes Reasonable and Prudent Alternatives (RPAs) 45, 47, 66, and 68. As part of implementing these RPAs, the Action Agencies have developed, and are in the process of implementing, pertinent parts of Caspian tern (Hydroprogne caspia) management plans (U.S. Fish and Wildlife Service, 2005; U.S. Army Corps of Engineers, 2015). This implementation includes redistributing nesting Caspian terns out of the Columbia River estuary and the mid-Columbia River region to reduce predation on salmonids listed under the Endangered Species Act. Previous studies have indicated that salmonids make up a small proportion of the diet of Caspian terns nesting in South San Francisco Bay, and that most smolts consumed by Caspian terns were hatcheryraised and non-listed (Evans and others, 2011; Collis and others, 2012), suggesting that development of Caspian tern nesting colonies in South San Francisco Bay may not affect endangered salmonids. Therefore, the Action Agencies developed Caspian tern and western snowy plover (Charadrius alexandrinus nivosus) habitat at the U.S. Fish and Wildlife Service Don Edwards San Francisco Bay National Wildlife Refuge (DENWR), California, prior to the 2015 nesting season.

To provide waterbird nesting habitat in South San Francisco Bay, the South Bay Salt Pond (SBSP) Restoration Project constructed 30 islands in Pond SF2 in 2010, and added 16 islands to 4 existing islands in Pond A16 of the DENWR in 2012 (fig. 1). However, since construction, nesting waterbirds have made limited use of these new islands. In 2015, seven of these islands were selected by the U.S. Fish and Wildlife Service, in conjunction with the USACE and Reclamation, and modified to provide habitat attractive to nesting Caspian terns and western snowy plovers. In Pond A16, two islands (Islands 11 and 12) were modified for nesting Caspian terns, and one island (Island 3) was modified for nesting snowy plovers (fig. 2). In Pond SF2, three islands (Islands 12, 17, and 21) were modified for nesting Caspian terns, and one island (Island 10) was modified for nesting snowy plovers (fig. 3). Islands modified for nesting snowy plovers were selected based on locations of snowy plover observations during previous breeding seasons, and islands modified for nesting Caspian terns were selected so that they were centrally located within the ponds but away from snowy plover islands. 
Islands modified for Caspian terns were groomed to a slope of 4 to 1 or less, were covered in 3/8-in. crushed rock 18 in. deep, and 3-in. rock was placed around the island perimeter. Islands modified for snowy plovers were covered with 1/4-in. crushed rock (Island 10 at Pond SF2) or 3/4-in. crushed rock (Island 3 at Pond A16) 5 in. deep, and a 6-ft buffer free of gravel was left around the edge of each island for plover foraging habitat. Island modifications were completed in February 2015.

To improve the likelihood that Caspian terns and snowy plovers would use these newly modified islands, social attraction measures (decoys and playback of adult vocalizations using call systems) were deployed beginning in 2015. Social attraction can be an effective wildlife-management technique whereby adult birds are attracted to potential nesting sites with decoys and bird calls to assist in the establishment of breeding colonies (Arnold and others, 2011; Jones and Kress, 2012). Colonial waterbirds, such as terns, are excellent candidate species for social attraction efforts because they are readily attracted to decoys of adult birds as well as sound recordings of adult vocalizations (Kress, 1983; Roby and others, 2002). Furthermore, the presence of conspecifics may influence selection of nest sites by snowy plovers (Patrick and Colwell, 2014), and the use of decoys and vocalizations may encourage nesting (California State Parks and Redwood National Park, 2014).

In coordination with USACE, Reclamation, and DENWR, the U.S. Geological Survey (USGS) implemented social attraction measures and monitoring activities during the first three nesting seasons following completion of island modifications in early 2015. Social attraction measures were intended to attract Caspian terns and snowy plovers to these recently modified islands during the 2015, 2016, and 2017 breeding seasons. Moreover, USGS conducted surveys twice weekly throughout the breeding season in all 3 years to monitor Caspian tern and snowy plover response to social attraction efforts and to evaluate project success.

The objectives of this project were to:

1. Deploy and maintain social attraction measures (decoys and call systems) for Caspian terns and snowy plovers on seven islands within Ponds A16 and SF2;

2. Monitor and evaluate nesting by Caspian terns and snowy plovers on the seven modified islands as well as surrounding islands of Ponds A16 and SF2;

3. Evaluate factors limiting breeding success of Caspian terns and snowy plovers at Ponds A16 and SF2;

4. Implement gull (Larus spp.) dissuasion efforts, as needed, in coordination with DENWR and U.S. Department of Agriculture Animal and Plant Health Inspection Service (USDAAPHIS)-Wildlife Services to limit potential negative effects of gulls on nesting Caspian terns and snowy plovers; and

5. Provide information, based on field observations, to DENWR, USACE, and USDA-APHIS on additional predator management options for limiting potential negative effects of other terrestrial and avian species on nesting Caspian terns and snowy plovers. 


\section{Methods}

\section{Social Attraction Measures for Caspian Terns and Snowy Plovers}

In late February to early March of 2015, 2016, and 2017, we deployed social attraction measures (decoys and call systems) on seven islands (three islands in Pond A16, four islands in Pond SF2). Five islands (Islands 11 and 12 in Pond A16; Islands 12, 17, and 21 in Pond SF2) each received 50-115 Caspian tern decoys arranged in the interior of each island, and spaced 1-1.5 m apart (table 1, figs. 4-6), which is the nest spacing commonly observed in Caspian tern colonies (Cuthbert and Wires, 1999). The number of decoys increased in later years as the manufacturer (Mad River Decoy, Waitsfield, Vermont) completed and delivered new decoys, and as more old decoys became available from partner agencies. The remaining two islands (Island 3 in Pond A16; Island 10 in Pond SF2) each received six snowy plover decoys in all 3 years of the study, arranged in male-female pairs at three locations on the island (fig. 7). We installed a call system (Murremaid Music Boxes, South Bristol, Maine) on each of the seven modified islands and broadcast either Caspian tern colony calls or snowy plover calls continuously through two omni-directional outdoor speakers. Each call system was powered by two 6-volt Optima ${ }^{\circledR}$ AGM batteries and charged by a 135 -watt Kyocera ${ }^{\odot}$ solar panel, enabling it to broadcast continuously without intervention. Call box and solar panels were deployed on the south side of each island, about 20 $\mathrm{m}$ from the decoy arrangement. Speakers were deployed on opposite ends of the decoys and connected to the call box by speaker wire that was buried under the gravel. We used a 20-minute recording of a winter flock of snowy plovers obtained from Little River State Beach in Humboldt County, California, supplied by Amber Transou of California State Parks, and a 42-minute recording of a breeding Caspian tern colony obtained from Rice Island (lower Columbia River estuary) by Kathy Turco of Alaska's Spirit Speaks. Caspian tern or snowy plover recordings were broadcast on a continuous loop at each island. The Caspian tern recording is the same one used in social attraction efforts at the other USACEconstructed sites in southeastern Oregon and northeastern California as part of implementing the Columbia River estuary Caspian tern management plans. Decoys and call systems broadcasting on a continuous loop remained on the islands until they were retrieved in August or September.

\section{Gull Dissuasion Efforts}

We visited Ponds A16 and SF2 at least 3-4 days a week for surveys and, if necessary, to haze gulls from islands (both modified islands and other islands nearby). The California gull (Larus californicus) population in San Francisco Bay has increased from fewer than 200 breeding gulls in 1982 to more than 38,000 breeding gulls in 2016 (Strong and others, 2004; Tarjan and Butler 2016). Gulls occur in large numbers around the project area, and have been identified as dominant predators of waterbird eggs and chicks (Herring and others, 2011; Ackerman, Herzog, Hartman, and Herring, 2014; Ackerman, Herzog, Hartman, and Takekawa, 2014). Thus, gull dissuasion was considered a potentially important component for successful nesting of Caspian terns and snowy plovers. Hazing measures included the use of green lasers and most often involved boating to islands and making noise to flush gulls from the islands. 


\section{Evaluation of Nesting by Caspian Terns and Snowy Plovers}

We conducted survey bouts at Ponds A16 and SF2 beginning in early March and extending through mid-September in 2015, 2016, and 2017 (total of 166 survey bouts). We conducted surveys 3-4 times per week early during the season (March-April) and then twice per week for the remainder of the breeding season (April-September). Both ponds were surveyed on the same day, one in the early morning and the other in the afternoon, and the time of day was alternated at each pond during consecutive survey bouts. Each survey bout was separated into three separate surveys, which were conducted from the surrounding levee using a 20-60× spotting scope.

First, a pond survey was conducted where we drove around the surrounding levee of each pond (A16 or SF2) by truck and stopped at set vantage points to record the number and location $(250 \times 250 \mathrm{~m}$ grid cell, figs. 2 and 3) of all tern, shorebird, and gull species known to nest in South San Francisco Bay, as well as potential nest predators (for example common raven [Corvus corax], raptors, and gulls). This survey was completed within 60 minutes to limit double-counting of individuals and avoid biasing abundance estimates at each pond.

Second, immediately following the pond survey, we conducted an additional 60-minute behavioral survey from a single fixed vantage point, where we scanned the pond every 10 minutes and documented the location and behaviors of all Caspian terns and snowy plovers. This survey was designed to provide breeding chronology information such as initiation of courtship, nest-building, and incubation, and to document factors negatively influencing nesting birds such as predation or disturbance.

Third, immediately following the behavioral survey, we conducted island surveys from a vantage point on the surrounding levee closest to each particular island, where we recorded the number of adults, the number of incubating adults, the number of nests with chicks, the number of chicks, and the number of fledglings of Caspian terns and snowy plovers observed on each island. In total, each survey bout consisted of about 150-180 minutes of observation. During each survey bout, we recorded color-band combinations of any color-banded Caspian tern observed.

Additionally in 2016 and 2017, we conducted separate weekly 2-hr band-resight surveys of Caspian terns at each of the Pond A16 and SF2 nesting colonies. During these surveys, we recorded any color-banded Caspian terns that were observed. These band-resight surveys were conducted from a small portable blind installed each day of the survey on an island (Pond A16) or internal levee (Pond SF2) that was adjacent to the focal nesting colony. During the band-resight surveys, we recorded the color combination and behaviors of all banded Caspian terns observed. These data were then provided to Yasuko Suzuki of Oregon State University to identify the origin of banded Caspian terns and potentially demonstrate the movement of terns from the Columbia River basin to the modified islands at the DENWR.

\section{Estimating Colony Size and Productivity of Caspian Terns}

Because it was important to project partners to limit disturbance of these newly formed colonies to avoid causing nest and (or) colony failures, visits to islands with active colonies were limited. Thus, we could not mark and follow the fates of individual nests to estimate the total number of nests within a colony over the course of the breeding season. Instead, we estimated the number of Caspian tern nests from direct counts of the number of active nests (sum of nests being incubated and nests with chicks) observed during our island surveys. In all years, Caspian terns were observed nesting over a 4-5-month period from mid-April through early September (fig. 8). Thus, the use of peak counts of active nests results in the underestimation of the number of total nests, as nests initiated early in the season or after the peak are not included. Moreover, in 2015, the number of nests initiated at both Ponds A16 and SF2 had a bimodal distribution with two distinct peaks. Concurrent increases in the number of adult Caspian terns during the second peak in nesting indicated that nests during the second peak were those of new 
nesting birds rather than renesting attempts (Hartman and others, 2016). As a result, using only the peak count in all years would underestimate production in 2015, whereas using the two peaks in 2015 but only the single peaks in 2016 and 2017 would underestimate the latter 2 years relative to 2015. To account for this, we used the following approach to estimate the total number of nests initiated in each year. First, we identified the date when the peak number of nests was observed in each year. Next, we determined the number of nests observed about 40 days prior to and about 40 days after the peak. If a survey occurred exactly 40 days before or 40 days after the date of the peak, we used the number of nests observed on those days. If not, we used the survey date closest to 40 days before and after the peak date. We selected this 40-day interval because each nest typically can be active for about 40 daysCaspian tern females lay 1-3 eggs with 2-3 days between laying each egg, incubate eggs over a 27-day period, and brood small chicks for 1 week post-hatch (Cuthbert and Wires 1999). Thus, nests active 40 days prior to and 40 days after the date the peak number of nests was observed would represent additional nests that would not have been active during the peak count. Therefore, for each year, we calculated the total number of nests as the number of nests active during the peak count, plus the number of nests active 40 days prior to the peak count, plus the number of nests active 40 days after the peak count. Additionally, if nests were active 80 days prior to and (or) 80 days after the peak, we also added these nests to the total (fig. 9). By including nests that could not have been active at the time of the peak count, this method provided a more realistic estimate of the total number of nests initiated over the entire breeding season.

We considered a chick fledged if it was similar in size to adults and had well-developed flight feathers, and (or) if it was observed flying. However, fledglings were observed over a 3-month period (mid-June through mid-September) at both Pond A16 and Pond SF2 (fig. 8), and many, if not most, of the fledglings observed in early September likely were not the same individuals observed in early July. To address this, we used the same procedure we used for estimating the total number of nests, in which we added the number of fledglings observed during the peak count, the number of fledglings observed 40 days prior to the peak count, and the number of fledglings observed 40 days after the peak count to estimate the number of fledglings produced in each year. Although fledglings, unlike nests, can move around and remain on the island for an indeterminate length of time, we thought that 40 days was a sufficient interval to minimize double counting of fledglings over the season. It was not necessary to add fledgling counts that occurred 80 days prior to or after the peak because no fledglings were observed at these times.

We used the total number of nests in each year to estimate the number of breeding pairs and estimated breeding success in each year as the number of fledglings per breeding pair by dividing the estimated number of fledged Caspian tern chicks produced by the estimated number of breeding pairs. Because Caspian terns may renest (lay a second clutch of eggs) following an unsuccessful first nesting attempt (Cuthbert and Wires, 1999), some late renests likely were included as new nests in estimating the number of breeding pairs. However, because we applied the same procedure to estimate the number of breeding pairs, the number of fledglings, and breeding success in all years, we could effectively determine the relative change in these measures among years. 


\section{Estimating Apparent Nest Density of Caspian Terns}

We calculated two measures of apparent nest density. First, we calculated nest density at each colony as a function of the total island area for that colony. Island areas were determined using RealTime Kinematics (RTK; Leica GNSS RTK Rover, Leica Geosystems, Atlanta, Georgia). During August 24-27, 2015, we traced the gravel perimeter of each island with the RTK unit while collecting latitude, longitude, and elevation data at 1-second intervals. These data were imported into ArcGIS ${ }^{\mathrm{TM}} 10.2$ (Environmental Research Systems Institute, Redlands, California) and converted to polygon shapefiles for determination of island area. Second, we calculated nest density at each colony as a function of only the area of the island used by the colony. For this second measure, we used aerial photographs of the colonies to map locations of tern nests on each island. We determined the area of each island used by nesting Caspian terns from digitized aerial colony photographs taken each year around the peak of nesting and provided by Real Time Research, Inc. (Bend, Oregon). From these photographs, we identified Caspian tern nests, created a minimum convex polygon shapefile around each colony in each year, and calculated colony area using $\operatorname{ArcGIS}^{\mathrm{TM}}$ 10.2. We calculated the number of nests per square meter of island area by dividing the number of nests observed on the island survey at the time the aerial colony photograph was taken by the total island area. We calculated the number of nests per square meter of colony area by dividing the number of nests observed on the island survey at the time the aerial colony photograph was taken by the total colony area. Both of these estimates are of apparent nest densities, not accounting for influences of nest depredation or nest abandonment (Mayfield, 1961), because we limited access to the islands during the nesting season to limit disturbance. Therefore, these density estimates are biased somewhat low.

\section{Results and Discussion}

\section{Abundance of Caspian Terns and Other Prominent Nesting Species in Ponds A16 and SF2}

Weekly high counts of the most abundant surveyed nesting species, and snowy plovers, at Ponds A16 and SF2 during all years are shown in figure 10. May and June are the primary nesting period for most waterbirds, including Caspian terns, in South San Francisco Bay. Thus, the number of individuals observed during these months is a good estimate of the breeding population, as few to no young of the year fledge before July. Caspian tern numbers at both ponds consistently increased throughout the 3year study. At Pond A16, the average count of Caspian terns in May and June increased 96 percent from 2015 (56 birds) to 2016 (110 birds), and increased another 41 percent from 2016 (110 birds) to 2017 (155 birds), for a 177-percent increase over the 3-year study period (fig. 11A). Similarly, at Pond SF2, the average count of Caspian terns in May and June increased 39 percent from 2015 (137 birds) to 2016 (190 birds), and increased another 63 percent from 2016 (190 birds) to 2017 (310 birds), for a 126percent increase over the 3-year study period (fig. 12A). Other abundant, although non-target, species that used islands in Ponds A16 and SF2 included American avocet (Recurvirostra Americana), blacknecked stilt (Himantopus mexicanus), California gull, and Forster's tern (Sterna forsteri). American avocet numbers increased more than 200 percent at both ponds in 2016 relative to 2015, before decreasing 59 percent (Pond A16) and 13 percent (Pond SF2) in 2017 (figs. 11B, 12B). Black-necked stilt numbers decreased 84 percent at Pond A16 from an average of 77 birds in 2015 to just 12 birds 2017 (fig. 11C). Black-necked stilt numbers at Pond SF2 were consistently low, but rose from an average of 4 birds in 2015 to 19 birds in 2017 (fig. 12C). California gulls, a major predator of waterbird eggs and chicks (Herring and others, 2011; Ackerman, Herzog, Hartman, and Herring, 2014; Ackerman, Herzog, Hartman, and Takekawa, 2014), were abundant at Pond A16 during all years. However, at Pond A16, the average count of California gulls in May and June decreased 57 percent from an average of 270 birds in 2015 to an average of 115 birds in 2017 (fig. 11D). This large decrease in California gull 
numbers at Pond A16 made gull dissuasion largely unnecessary in 2016 and 2017. At Pond SF2, the number of California gulls in May and June was consistently low, with counts averaging 6 or fewer birds in all years (fig. 12D). Counts of Forster's terns in May and June at Pond A16 consistently averaged 15-21 birds throughout the study (fig. 11E), but at Pond SF2, Forster's tern numbers increased 248 percent from an average of only 23 birds in May and June of 2015 to an average of 80 birds in May and June of 2017 (fig. 12E). Finally, western snowy plover observations were infrequent and numbers were consistently low (average $\leq 8$ birds) at both sites. Western snowy plovers increased over the study period at Pond A16 (fig. 11F), but were not observed at Pond SF2 during 2016 or 2017 (fig. 12F).

Caspian terns were observed at least once on each of the 20 islands in Pond A16 (including all 3 modified islands) and on each of 24 islands in Pond SF2, (including all 4 modified islands) (table 2). At Ponds A16 and SF2, Caspian terns were overwhelmingly drawn to those islands with Caspian tern social attraction measures. During the 166 behavioral surveys conducted from March to September of 2015, 2016, and 2017, 92 and 93 percent of Caspian tern observations in Ponds A16 and SF2, respectively, occurred on islands with social attraction measures for Caspian terns (fig. 13).

\section{Breeding Chronology of Caspian Terns}

Caspian terns were observed at Ponds A16 and SF2 from mid- to late March through midSeptember, when surveys ended, during all years of the project. However, breeding chronology was about 2-3 weeks earlier at Pond SF2 than at Pond A16 throughout the 3-year study (fig. 14). At Pond SF2, courtship consistently began in late March, nest building began in mid- to late March, and adults were first observed incubating eggs in early to late April. Brooding of tern chicks at Pond SF2 was first observed 4 weeks later in early to late May. In contrast, at Pond A16, courtship began in late March or early April, nest building began in mid- to late April, and incubation was first observed in late April. Brooding of chicks at Pond A16 followed 4 weeks later in late May. At both ponds, Caspian terns concluded nesting and brooding chicks by early September.

Caspian terns at Pond SF2 began incubating eggs about 1 week earlier in 2016, and 2 weeks earlier in 2017, relative to 2015 (fig. 14). At Pond A16, terns began incubating eggs about 1 week earlier in 2016 and 2017, relative to 2015 (fig. 14). The reason for this advancement in breeding chronology is unknown but may be partially due to tern familiarity with this new nesting site in the years subsequent to initial colonization in 2015.

The nesting season at Ponds A16 and SF2 was longer than has been observed for Caspian terns in other San Francisco Bay locations. Roby and others (2009) reported that by early August 2009, three Caspian tern colonies in San Francisco Bay had completed nesting and were abandoned for the season. In contrast, pre-fledged chicks continued to be observed as late as early September at Ponds A16 and SF2 (fig. 8).

\section{Size, Productivity, and Growth of Caspian Tern Breeding Colonies}

Caspian terns consistently nested on Island 11 in Pond A16 and on Island 21 in Pond SF2 (table 3; figs. 8, 15, and 16). Except for a single nest on Island 17 in Pond SF2 in 2015, terns did not nest on the other 3 islands modified for Caspian terns (Island 12 in Pond A16, Islands 12 and 17 in Pond SF2). Peak counts of the total number of active nests (which include both nests with eggs and nests with chicks) on Island 11 in Pond A16 occurred on June 5 (n=29 nests, first peak) and again on July 20 (n=44 nests, second peak) for a combined total of 73 nests in 2015, on June 6 in 2016 ( $n=137$ nests), and on June 9 in 2017 ( $n=167$ nests). The peak number of nests at Island 11 in Pond A16 increased 88 percent in 2016, and increased another 22 percent in 2017, for a 129-percent increase over the 3-year study period. For 2015, we estimated the total number of nests on Island 11 in Pond A16 by summing the peak number of 44 nests observed on July 20, 22 nests observed on June 8 (42 days before the peak), and 13 nests observed on May 1 (80 days before the peak), for a total of 79 nests (fig. 9). For 2016, we summed 
the peak number of 137 nests observed on June 6, 9 nests observed on April 27 (40 days before the peak), 20 nests observed on July 18 (42 days after the peak), and 3 nests observed on August 26 (81 days after the peak), for a total of 169 nests (fig. 9). Finally, for 2017, we summed the peak number of 167 nests observed on June 9, 5 nests observed on April 28 (42 days before the peak), 52 nests observed on July 21 (42 days after the peak), and 3 nests observed on August 28th (80 days after the peak), for a total of 227 nests (fig. 9). Using these total nest values, we estimated that the Caspian tern colony at Island 11 in Pond A16 increased 114 percent in 2016, and increased another 34 percent in 2017, for a 187-percent increase over the 3-year study period (fig. 17).

Peak counts of the total number of active nests on Island 21 in Pond SF2 occurred on May 29 ( $\mathrm{n}=57$ nests, first peak) and again on June 19 ( $\mathrm{n}=93$ nests, second peak) for a combined total of 150 nests in 2015, on June 3 in 2016 ( $n=180$ nests), and on June 9 in 2017 ( $n=334$ nests). The peak number of nests at Island 21 in Pond SF2 increased 20 percent in 2016, and increased another 86 percent in 2017, for a 123-percent increase over the 3-year study period. For 2015, we estimated the total number of nests on Island 21 in Pond SF2 by summing the peak number of 93 nests observed on June 19, 49 nests observed on May 8 (42 days before the peak), and 23 nests observed on July 31 (42 days after the peak), for a total of 165 nests (fig. 9). For 2016, we summed the peak number of 180 nests observed on June 3, 28 nests observed on April 25 (39 days before the peak), 54 nests observed on July 15 (42 days after the peak), and 3 nests observed on August 22 (80 days after the peak), for a total of 265 nests (fig. 9). Finally, for 2017, we summed the peak number of 334 nests observed on June 9, 28 nests observed on April 28 (42 days before the peak), 74 nests observed on July 21 (42 days after the peak), and 1 nest observed on August 31 (83 days after the peak), for a total of 437 nests (fig. 9). Using these total nest values, we estimated that the Caspian tern colony at Island 21 in Pond SF2 increased 61 percent in 2016, and increased another 65 percent in 2017, for a 165-percent increase over the 3-year study period (fig. 17).

Summing the total number of nests on Ponds A16 and SF2 resulted in an overall estimated 245 breeding pairs in 2015 (including the single nest observed on Island 17), 434 in 2016, and 664 in 2017 (table 3). In recent years, only the Brooks Island Caspian tern colony produced more nests ( $\mathrm{n}=681$ in 2009; Roby and others, 2009) in San Francisco Bay than was produced between Ponds A16 and SF2 in 2017. The overall number of Caspian tern breeding pairs at Ponds A16 and SF2 increased 77 percent in 2016, and increased another 53 percent in 2017, for a 171-percent increase over the 3-year study period (table 3; fig. 17).

Peak counts of the number of fledglings on Island 11 in Pond A16 occurred on July 13 ( $\mathrm{n}=22$, first peak) and again on August 21 ( $n=32$, second peak) for a combined total of 54 in 2015, on August 1 in 2016 ( $n=35)$, and on August 7 in 2017 ( $n=95)$. The peak number of fledglings at the Caspian tern colony at Island 11 in Pond A16 decreased 35 percent in 2016, and increased 171 percent in 2017, for a 76-percent increase over the 3-year study period. For 2015, we estimated the total number of fledglings on Island 11 in Pond A16 by summing the peak number of 32 fledglings observed on August 21, and 22 fledglings observed on July 13 (39 days before the peak), for a total of 54 fledglings (fig. 9). For 2016, we summed the peak number of 35 fledglings observed on August 1, 11 fledglings observed on June 24 (38 days before the peak), and 5 fledglings observed on September 12 (42 days after the peak), for a total of 51 fledglings (fig. 9). Finally, for 2017, we summed the peak number of 95 fledglings observed on August 7, 3 fledglings observed on June 26 (42 days before the peak), and 8 fledglings observed on September 19 (42 days after the peak), for a total of 106 fledglings (fig. 9). Using these total fledgling values, we estimated that the number of fledglings at the Caspian tern colony at Island 11 in Pond A16 decreased 6 percent in 2016, and increased 108 percent in 2017, for a 96 percent increase over the 3-year study period (fig. 17). 
Peak counts of the number of fledglings on Island 21 in Pond SF2 occurred on July 6 (n=75, first peak) and again on August 21 ( $n=44$, second peak) for a combined total of 119 in 2015, on July 8 in $2016(n=55)$, and on July 14 in $2017(n=120)$. The peak number of fledglings at the Caspian tern colony at Island 21 in Pond SF2 decreased 54 percent in 2016, and increased 118 percent in 2017, for a 1percent increase over the 3-year study period. For 2015, we estimated the total number of fledglings on Island 21 in Pond SF2 by summing the peak number of 75 fledglings observed on July 6, and 39 fledglings observed on August 17 (42 days after the peak), for a total of 114 fledglings (fig. 9). For 2016, we summed the peak number of 55 fledglings observed on July 8, and 17 fledglings observed on August 19 (42 days after the peak), for a total of 72 fledglings (fig. 9). Finally, for 2017, we summed the peak number of 120 fledglings observed on July 14, and 13 fledglings observed on August 25 (42 days after the peak), for a total of 133 fledglings (fig. 9). Using these total fledgling values, we estimated that the number of fledglings at the Caspian tern colony at Island 21 in Pond SF2 decreased 37 percent in 2016, and increased 85 percent in 2017, for a 17-percent increase over the 3-year period (fig. 17). Summing the total number of fledglings on Ponds A16 and SF2 resulted in an overall estimated 169 fledglings in 2015 (including the single fledgling from the one nest observed on Island 17), 123 fledglings in 2016, and 239 fledglings in 2017 (table 3). The overall number of Caspian tern fledglings produced at Ponds A16 and SF2 decreased 27 percent in 2016, and increased 94 percent in 2017, for a 41 percent increase over the 3-year study period (table 3; fig. 17).

Dividing the estimated number of fledglings by the estimated number of breeding pairs yielded an apparent breeding success (number of fledglings per breeding pair) of 0.68 in 2015, 0.30 in 2016, and 0.47 in 2017 at Island 11 in Pond A16 (table 3). Apparent breeding success at Pond A16 decreased 56 percent in 2016, increased 55 percent in 2017, and decreased 32 percent over the 3-year study period (table 3; fig. 17). At Island 21 in Pond SF2, apparent breeding success was 0.69 in 2015, 0.27 in 2016 , and 0.30 in 2017, resulting in a 61 percent decrease in 2016, a 12 percent increase in 2017, and a 56 percent decrease over the 3-year study period (table 3; fig. 17). Overall apparent breeding success for Ponds A16 and SF2 combined was 0.69 in 2015, 0.28 in 2016, and 0.36 in 2017, representing a 59 percent decrease in 2016, a 27 percent increase in 2017, and a 48 percent decrease over the 3-year study period (table 3; fig. 17). Decreases in apparent breeding success between years were largely the result of increases in the number of breeding pairs without proportional increases (and in some cases decreases) in the number of fledglings produced (table 3). However, limitations associated with estimating the total number of fledglings from peak counts likely led to underestimation of the number of fledglings produced and, therefore, breeding success. The average breeding success rate over the course of the 3year project was 0.44 fledglings per breeding pair, lower than the long-term averages on East Sand Island (about 0.62) and Crescent Island (0.53) in the mid-Columbia River (Roby and others, 2013), but greater than the average among sites in South San Francisco Bay (0.27; Collis and others, 2012).

\section{Island Area and Nest Density of Caspian Terns}

The island area used by Caspian tern colonies increased in size each year of the study (figs. 15 and 16) - $366 \mathrm{~m}^{2}$ in 2015, $747 \mathrm{~m}^{2}$ in 2016, and 1,394 $\mathrm{m}^{2}$ in 2017 (table 3). This corresponded to a 104 percent increase in 2016, another 87 percent increase in 2017, and a 281 percent increase over the 3-year study period. Owing to its much larger population, the colony on Island 21 in Pond SF2 occupied a much larger proportion of the island habitat than did the colony on Island 11 in Pond A16. By 2017, 29 percent and 55 percent of the island area available was occupied by nesting terns on Island 11 in Pond A16 (1,603 $\left.\mathrm{m}^{2}\right)$ and Island 21 in Pond SF2 (1,693 $\left.\mathrm{m}^{2}\right)$, respectively. 
Apparent nesting density as a function of total island area available (nests per square meter of island area) also increased over the study period (table 3). On Island 11 in Pond A16, nests per island area increased 258 percent in 2016, increased another 59 percent in 2017, and increased 469 percent over the 3-year study. Similarly, on Island 21 in Pond SF2, nests per island area increased 175 percent in 2016, increased another 62 percent in 2017, and increased 347 percent over the 3-year study period. Apparent nesting density as a function of only the island area used by Caspian terns also increased over the study period (table 3; fig. 17). On Island 11 in Pond A16, nests per colony area increased 75 percent in 2016, decreased 8 percent in 2017, and increased 61 percent over the 3-year study period. Similarly, on Island 21 in Pond SF2, nests per colony area increased 35 percent in 2016, decreased 16 percent in 2017, and increased 13 percent over the 3-year study period. Overall nest density (nests per square meter of colony area) in Ponds A16 and SF2 was higher in 2017 (0.29) and 2016 (0.33) compared to 2015 (0.23), and was lower than densities observed at San Francisco Bay sites of Brooks Island (0.9), Eden Landing (1.0), and Steven's Creek (0.5; Roby and others, 2009). These results suggest that, for two reasons, considerable room remains for colony population increases. First, large majorities of modified island habitat are still not being used by nesting Caspian terns. This includes 71 percent of the area of Island 11 in Pond A16, 45 percent of the island area of Island 21 in Pond SF2, and 100 percent of the island area of Island 12 in Pond A16 and Islands 12 and 17 in Pond SF2 (total of 6,509 $\mathrm{m}^{2}$ of island area modified for nesting Caspian terns not used in 2017). Second, in 2017, overall nest density between Ponds A16 and SF2 was 0.29 nests per colony area, lower than the $0.5-1.0$ breeding pairs per $\mathrm{m}^{2}$ of colony area that has been observed at other colonies in San Francisco Bay (Roby and others, 2009).

\section{Sightings of Color-Banded Caspian Terns}

We observed 52 uniquely banded Caspian terns over the course of the 3-year study, including 5 in 2015, 26 in 2016, and 38 in 2017 (table 4). Eight banded terns were observed only on Island 11 in Pond A16, 37 were observed only on Islands 17 and (or) 21 in Pond SF2, 3 were observed elsewhere in Pond SF2, and 4 were observed on both Island 11 in Pond A16 and Island 21 in Pond SF2. A total of 27 of these color-banded Caspian terns were observed engaging in breeding behaviors (that is, copulation, nest scraping, courtship feeding, incubation, or attending to, feeding, or brooding a chick), including two in Pond A16, 24 in Pond SF2, and one at both sites.

All information regarding site of initial banding was provided courtesy of Kirsten Bixler and Yasuko Suzuki (Oregon State University, written commun., November 9, 2017). Among the 27 colorbanded Caspian terns suspected or confirmed to have bred at Pond A16 or Pond SF2, 3 were banded as adults and 15 were banded as chicks during 2004-2009 at Brooks Island in San Francisco Bay; 2 were banded as chicks in 2009 at Eden Landing in San Francisco Bay; 3 were banded as chicks during 20032010 at East Sand Island in the Columbia River estuary, Oregon; 1 was banded as a chick in 2012 at Sheepy Lake on the Lower Klamath National Wildlife Refuge, 1 was banded as a chick in 2011 on Goose Island in Potholes Reservoir, Washington; 1 was banded as a chick in 2010 at the Port of Bellingham in Bellingham Bay, Washington; and 1 for which we could not determine the banding location or year because the bird was missing bands (table 4). When the number of breeding Caspian terns previously banded at either Brooks Island or Eden Landing $(n=20)$ were combined, 74 percent of the 27 color-banded terns observed breeding at Pond A16 or Pond SF2 originated from colonies within San Francisco Bay. This suggests that Island 11 in Pond A16 and Island 21 in Pond SF2 have been largely colonized by Caspian terns from other breeding sites in San Francisco Bay. Nevertheless, at least three Caspian terns banded as chicks at the East Sand Island colony in the Columbia River estuary attempted to breed at either Pond A16 or Pond SF2 on the Don Edwards San Francisco Bay National Wildlife Refuge in 2017, and two were confirmed attending young chicks. This indicates success in one goal of the project-relocating Caspian terns from the Columbia River estuary to San Francisco Bay. 


\section{Nesting of Snowy Plovers and Other Waterbirds}

Snowy plovers were uncommon at Ponds A16 and SF2, both before and during the 3-year study period, with most observations occurring before or after the nesting season (fig. 10). At Pond A16, snowy plover numbers in May and June averaged fewer than three individuals in 2015 and 2016 (fig. 11). However, in 2017, snowy plover numbers in May and June averaged eight individuals, and six nests were documented. We observed three nests on Island 11 on April 21 and another three nests on Island 12 on May 2. Both of these islands were modified, and had active social attraction measures for nesting Caspian terns. No snowy plover nested on Island 3 in Pond A16, the island that was specifically modified for nesting snowy plovers and contained snowy plover social attraction measures. All six snowy plover nests in 2017 were unsuccessful and no chicks were ever observed. Caspian terns did cause some disturbance to snowy plovers nesting on Island 11, occasionally flying overhead, landing or walking close to the nest and causing the attending parent to flush. However, snowy plovers would quickly return to the nest after such encounters. All three snowy plover nests on Island 11 in Pond A16 were outside the perimeter of the Caspian tern colony, whereas the three nests on Island 12 were among the Caspian tern decoys and along the decoy perimeter (no terns nested on Island 12). At Pond SF2, snowy plover numbers in May and June dropped from an average of six individuals in 2015 to no birds in either 2016 or 2017 (fig. 12), and no nests were observed throughout the 3-year study period.

American avocets, Forster's terns, black-necked stilts, and black skimmers (Rynchops niger) were other common nesting waterbird species in Ponds A16 and (or) SF2. These species nested on islands or on mudflats within these ponds. At Pond A16, the number of American avocet nests increased from 4 in 2015 to 89 in 2016 before decreasing to 79 in 2017. The number of black-necked stilt nests increased from 0 in 2015 to 5 in 2016 before decreasing to 1 in 2017. No other waterbirds nested in Pond A16 during the study. At Pond SF2, the number of American avocet nests increased from 25 in 2015 to 121 in 2016 before decreasing to 72 in 2017. The number of Forster's tern nests increased from 0 in 2015 to 8 in 2016, then to 170 in 2017. The 178 Forster's tern nests in Pond SF2 in 2016 and 2017 are the first documented nests of this species at Pond SF2 over the past 13 years of nest monitoring efforts by USGS. The number of Forster's tern nesting colonies and the overall number of Forster's tern nests have been decreasing in South San Francisco Bay over the past several years. In 2017, only 4 large Forster's tern nesting colonies (one of which was in Pond SF2) were documented in South San Francisco Bay, down from the 10-20 colonies observed in previous years (J.T. Ackerman, M.P Herzog, and C.A. Hartman, U.S. Geological Survey, unpub. data, 2018). In 2015 and 2016, DENWR staff deployed Forster's tern decoys and call systems on Island 22 in Pond SF2. Although no tern nests were observed on this or nearby islands in any year, this social attraction effort may have helped attract Forster's terns to nest in other areas of Pond SF2 in 2017. There also were 15-20 black skimmer nests in Pond SF2 in 2017, the first documented nests of this species at Pond SF2 over the past 13 years of nest monitoring efforts by USGS. Black skimmers nested on several islands in Pond SF2, including all three islands with Caspian tern social attraction (Islands 12, 17, and 21). Black skimmers were largely successful, as about 30-35 chicks fledged and we observed no conflict or disturbance between black skimmers and Caspian terns. Caspian tern social attraction efforts, and the presence of Caspian tern nesting colonies in Ponds A16 and SF2 during 2015, 2016, and 2017 may have attracted other nesting waterbirds (particularly American avocet, Forster's terns, and black skimmers) to nest in these ponds as well, and, thus, may be an indirect benefit of the Caspian tern social attraction efforts. 


\section{Gull Dissuasion}

California gull numbers decreased at Ponds A16 and SF2 over the 3-year study period (figs. 11 and 12). At Pond A16, California gull numbers in May and June decreased 57 percent from an average of 270 in 2015 to 115 in 2017. At Pond SF2, May and June California gull numbers were consistently low and averaged fewer than 6 individuals in all years. Gulls typically roosted on the modified islands less often than on other islands. This, coupled with the much lower gull numbers relative to 2015, made gull hazing largely unnecessary in 2016 and 2017. We never observed gulls prospecting for nest sites, building nests, or engaging in other nesting behaviors at either Ponds A16 or SF2.

The greater number of gulls at Pond A16 compared to Pond SF2 likely is owing partly to the greater distance of Pond SF2 to the nearest breeding gull colony and to the nearest landfill, which attracts large numbers of gulls (Ackerman, Eagles-Smith, and others, 2009). The distance from modified islands in Pond A16 to the nearest gull colony is less than $3 \mathrm{~km}$, whereas the distance from modified islands in Pond SF2 to the nearest gull colony is more than $5 \mathrm{~km}$ (fig. 1). Additionally, the density of breeding gulls is much greater around Pond A16 than around Pond SF2 (fig. 1). Furthermore, the distance from modified islands in Pond A16 to the nearest landfill (Newby Island) is about $2 \mathrm{~km}$, whereas the distance from modified islands in Pond SF2 to the nearest landfill (Newby Island) is more than $16 \mathrm{~km}$. Finally, gulls likely were attracted to Pond A16 because it lies almost directly between the large A9/A10 gull colony and the Newby Island Landfill (Ackerman, Eagles-Smith, and others, 2009; fig. 1).

\section{Factors Influencing Overall Success of Caspian Tern Colonies}

Potential egg or chick predators observed at Ponds A16 and SF2 included California gulls, ringbilled gulls (Larus delawarensis), western gulls (L. occidentalis), American crows (Corvus brachyrhynchos), and common ravens. Of these, California gulls were by far the most numerous, and are well-documented predators of waterbird eggs and chicks in South San Francisco Bay (Herring and others, 2011; Ackerman, Herzog, Hartman, and Herring, 2014; Ackerman, Herzog, Hartman, and Takekawa, 2014). California gulls were particularly abundant at Pond A16. However, California gull numbers at Pond A16 decreased considerably in 2016 and 2017 relative to 2015 (fig. 11), and gull numbers typically only exceeded 300 individuals after late July. Gulls in Pond A16 typically were observed roosting on islands and the surrounding pond levees, and there was little evidence that California gulls had a large negative influence on nesting Caspian terns. On June 2, 2016, a California gull was observed depredating an abandoned Caspian tern nest at the edge of the colony on Island 11 in Pond A16, and on July 1, 2016, a California gull unsuccessfully attempted to steal a fish from a Caspian tern chick. There were fewer gulls at Pond SF2 than at Pond A16 (fig. 12), and gulls were largely absent from the pond from mid-April to mid-July. Gulls rarely roosted on Pond SF2 islands modified for Caspian terns. However, on a few occasions in June 2017, two gulls were observed disturbing the Caspian tern colony at Pond SF2, including the successful depredation of a young tern chick. On July 3, USDA-APHIS removed one of these gulls, and gull disturbance of the colony ceased for the remainder of the breeding season.

In late September, at the time decoys and call systems were removed, we observed several dead Caspian tern chicks at both Caspian tern nesting islands, which is typical among colonial waterbird nesting colonies. The number of dead chicks and fledglings observed was greater in $2015(\mathrm{n}=55)$ and $2016(n=63)$ than in $2017(n=30)$. Causes of mortality for these chicks and fledglings is unknown, but there were no obvious signs of trauma, suggesting that these individuals died because of exposure, starvation, abandonment, and (or) other natural causes. 


\section{Conclusions and Management Implications}

Results from the 2015, 2016, and 2017 breeding seasons demonstrate the success of social attraction measures in establishing Caspian tern (Hydroprogne caspia) breeding colonies on modified islands at Ponds A16 and SF2 of the Don Edwards San Francisco Bay National Wildlife Refuge, California. Over the 3-year study, we estimate that 1,343 Caspian tern nests were initiated and 531 chicks fledged between the two ponds. Prior to 2015, the first year of the study, there were no records of Caspian terns nesting at either Pond A16 or Pond SF2. However, by 2017, we estimated that 664 Caspian tern breeding pairs nested and at least 239 chicks fledged at Ponds A16 and SF2, making these two ponds home to two of the largest Caspian tern breeding colonies in San Francisco Bay. The proportion of modified island area occupied by Caspian tern nesting colonies almost doubled in 2017 (1,394 square meters [ $\left.\mathrm{m}^{2}\right]$ ) compared to $2016\left(747 \mathrm{~m}^{2}\right)$, encompassing 29 and 55 percent of the available nesting habitat on Island 11 in Pond A16 and Island 21 in Pond SF2, respectively. Even with the increase in island area used by Caspian terns in 2017, the complete lack of nesting on three of the five modified islands resulted in use of only 18 percent $\left(1,394 \mathrm{~m}^{2}\right)$ of the 7,903- $\mathrm{m}^{2}$ area modified on five islands for nesting Caspian terns in Ponds A16 and SF2. This suggests that there is considerable opportunity for Caspian tern breeding colonies to expand at each pond in future years.

Of the 52 banded Caspian terns observed at Ponds A16 and SF2 in 2016, 27 were observed to be engaged in breeding behaviors. The other 25 were mostly observed in early spring and (or) late summer, suggesting that they bred at other locations and only passed through Ponds A16 and SF2 before and after the breeding period. Twenty of the 27 color-banded Caspian terns observed engaging in breeding behaviors were banded at other Caspian tern breeding sites in San Francisco Bay (Brooks Island or Eden Landing), whereas 3 of the 27 were banded as chicks on East Sand Island in the Columbia River estuary. Thus, although Caspian terns from other colonies in San Francisco Bay likely constitute a large proportion of the Caspian terns at the new colonies at Ponds A16 and SF2, we documented evidence of three individuals (two of which were observed attending chicks) moving from their natal colony of East Sand Island colony in the Columbia River estuary to breed at the Don Edwards San Francisco Bay National Wildlife Refuge.

We found little evidence that the large population of California gulls (Larus californicus) in South San Francisco Bay had a negative effect on nesting Caspian terns. In fact, compared to 2015, California gull numbers in 2016 and 2017 were markedly lower at Pond A16, and gull numbers at both Ponds A16 and SF2 were relatively low throughout most of the breeding season, only increasing in August and September. However, as the islands in Pond SF2 and especially Pond A16 are relatively new, continued monitoring, as well as hazing, may be necessary to ensure that this attractive nesting habitat is not overtaken by nesting gulls.

Snowy plovers (Charadrius alexandrinus nivosus) did not nest on the two islands modified for them in any year but did nest on Islands 11 and 12 modified for Caspian terns in Pond A16 in 2017. Although modifying and deploying snowy plover social attraction measures on a separate island (Island

3 in Pond A16) was not successful in keeping nesting Caspian terns and snowy plovers separate, we did not observe major disturbance to nesting snowy plovers by Caspian terns. Overall, there was little observed conflict between Caspian terns and snowy plovers associated with island modifications in Ponds A16 and SF2. 
Prior to island modification and deployment of social attraction measures in 2015, there was no history of Caspian terns nesting at either Pond A16 or Pond SF2. In just 3 years, the number of nesting Caspian terns in Ponds A16 and SF2 has increased from 0 to more than 650 breeding pairs and 230 fledglings, becoming the largest Caspian tern breeding colonies in South San Francisco Bay. Successful establishment of Caspian tern colonies in Ponds A16 and SF2 in 2015, and colony expansion in 2016, and again in 2017, demonstrate the potential of social attraction measures to help establish waterbird nesting colonies in San Francisco Bay. To offset the loss of managed pond habitat from tidal marsh restoration, the South Bay Salt Pond Restoration Project has constructed 46 new islands (16 in Pond A16, 30 in Pond SF2) over the past 5 years to provide nesting and roosting habitat for waterbirds (7 of these islands were further modified for nesting Caspian terns and snowy plovers in 2015 and are the focus of the current study). However, these other recently constructed islands thus far have been used relatively little by nesting waterbirds, particularly Forster's terns (Sterna forsteri), one of the most abundant colonial-breeding waterbirds in South San Francisco Bay. Continued social attraction measures similar to those used in this study may help to establish breeding colonies of several species at targeted wetlands enhanced by the South Bay Salt Pond Restoration Project.

\section{Acknowledgments}

We thank the U.S. Army Corps of Engineers for project support and the U.S. Fish and Wildlife Service Don Edwards San Francisco Bay National Wildlife Refuge Complex and the South Bay Salt Pond Restoration Project for logistical and project support. We also thank Kimberly Sawyer, Jeanne Fasan, Janel Mayo, Sam Lei, Andrea Mott, Breanne Cooney, and Sami Michishit of the U.S. Geological Survey for assistance in the field; Kathy Turco of Alaska's Spirit Speaks for the Caspian tern colony recording; Amber Transou of California State Parks for the western snowy plover recording; and the San Francisco Bay Bird Observatory for California gull data.

\section{References Cited}

Ackerman, J.T., Eagles-Smith, C., Takekawa, J., Bluso-Demers, J., Tsao, D., and Le Fer, D., 2009, California gull movements in relation to nesting waterbirds and landfills-Implications for the South Bay Salt Pond Restoration Project—Data summary: U.S. Geological Survey, Western Ecological Research Center, Davis, California, 64 p.

Ackerman, J.T., Herzog, M.P., Hartman, C.A., and Herring, G., 2014, Forster's tern chick survival in response to a managed relocation of predatory California gulls: Journal of Wildlife Management, v. 78, no. 5, p. 818-829.

Ackerman, J.T., Herzog, M.P., Hartman, C.A., and Takekawa, J.Y., 2014, Comparative reproductive biology of sympatric species-Nest and chick survival of American avocets and black-necked stilts: Journal of Avian Biology, v. 45, p. 609-623.

Arnold, J.M., Nisbet, I.C.T., and Veit, R., 2011, Assessing aural and visual cueing as tools for seabird management: Journal of Wildlife Management, v. 75, no. 3, p. 495-500.

California State Parks and Redwood National Park, 2014, Western snowy plover annual report 20122013: California State Parks, North Coast Redwoods District; and Redwood National Park, 36 p.

Collis, K., Roby, D.D., Larson, K.W., Adrean, L.J., Nelson, S.K., Evans, A.F., Hostetter, N., Battaglia, D., Lyons, D.E., Marcella, T., and Patterson, A., 2012, Trends in Caspian tern nesting and diet in San Francisco Bay-Conservation implications for terns and salmonids: Waterbirds, v. 35, no. 1, p. $25-34$. Cuthbert, F.J., and Wires, L.R., 1999, Caspian tern (Hydroprogne caspia), in Poole, A., ed., The birds of North America online: Ithaca, New York, Cornell Lab of Ornithology.

Evans, A.F., Roby, D.D., Collis, K., Cramer, B.M., Sheggeby, J.A., Adrean, L.J., Battaglia, D.S., and Lyons, D.E., 2011, Recovery of coded wire tags at a Caspian tern colony in San Francisco Bay-A 
technique to evaluate impacts of avian predation on juvenile salmonids: North American Journal of Fisheries Management, v. 31, no. 1, p. 79-87.

Hartman, C.A., Ackerman, J.T., Herzog, M.P., Strong, C.M., Trachtenbarg, D., Sawyer, K., and Shore, C., 2016, Evaluation of Caspian tern (Hydroprogne caspia) and snowy plover (Charadrius alexandrinus nivosus) nesting on modified islands at the Don Edwards San Francisco Bay National Wildlife Refuge-2015 annual report: U.S. Geological Survey Open-File Report 2016-1049, 36 p.

Herring, G., Ackerman, J.T., Takekawa, J.Y., Eagles-Smith, C.A., and Eadie, J.M., 2011, Identifying nest predators of American avocets (Recurvirostra americana) and black-necked stilts (Himantopus mexicanus) in San Francisco Bay, California: Southwestern Naturalist, v. 56, no. 1, p. 35-43.

Jones, H.P., and Kress, S.W., 2012, A review of the world's active seabird restoration projects: Journal of Wildlife Management, v. 76, no. 1, p. 2-9.

Kress, S.W., 1983, The use of decoys, sound recordings, and gull control for re-establishing a tern colony in Maine: Colonial Waterbirds, v. 6, no. 1983, p. 185-196.

Mayfield, H., 1961, Nesting success calculated from exposure: Wilson Bulletin, v. 73, p. 255-261. Patrick, A.M., and Colwell, M.A., 2014, Snowy plovers select wide beaches for nesting: Wader Study Group Bulletin, v. 121, no. 2, p. 17-20.

Roby, D.D., Collis, K., Adrean, L.J., Battaglia, D.S., Lyons, D.E., Nelson, S.K., Patterson, A., Spiegel, C., Suzuki, Y., Wolf, C., 2009, Caspian tern nesting ecology and diet in San Francisco Bay and interior Oregon-Draft 2009 annual report: Prepared for the U.S. Army Corps of Engineers, 78 p.

Roby, D.D., Collis, K., Lyons, D., Adkins, J., Suzuki, Y., Loschl, P., Lawes, T., Bixler, K., PeckRichardson, A., Patterson, A., Collar, S., Piggott, A., Davis, H., Mannas, J., and others, 2013, Research, monitoring, and evaluation of avian predation on salmonid smolts in the lower and midColumbia River-2013 final annual report: Prepared for Bonneville Power Administration, U.S. Army Corps of Engineers, and Grant County Public Utility District, 251 p.

Roby, D.D., Collis, K., Lyons, D.E., Craig, D.P., Adkins, J.Y., Myers, A.M., and Suryan, R.M., 2002, Effects of colony relocation on diet and productivity of Caspian terns: Journal of Wildlife Management, v. 66, no. 3, p. 662-673.

Strong, C.M., Spear, L.B., Ryan, T.P., and Dakin, R.E., 2004, Forster’s tern, Caspian tern, and California gull colonies in San Francisco Bay-Habitat use, numbers and trends, 1982-2003: Waterbirds, v. 27, no. 4, p. 411-423.

Tarjan, M., and Butler, K.B., 2016, Citizen science-based colonial waterbird monitoring-2016 nesting summary: San Francisco Bay Bird Observatory, accessed July 2018, at https://www.sfbbo.org/uploads/1/1/6/7/116792187/sfbbo_waterbird_nesting_summary_2016.pdf. U.S. Army Corps of Engineers, 2015, Caspian tern nesting habitat management, East Sand Island, Clatsop County, Oregon-Final environmental assessment: U.S. Army Corps of Engineers, Portland Oregon, 12 p., 25 p., http://www.nwp.usace.army.mil/portals/24/docs/announcements/ea/final_cate_ea.pdf.

U.S. Fish and Wildlife Service, 2005, Caspian tern management to reduce predation of juvenile salmonids in the Columbia River Estuary_Final environmental impact statement: U.S. Fish and Wildlife Service, Portland, Oregon, https://www.fws.gov/pacific/migratorybirds/pdf/Caspian_Tern_Final_EIS.pdf. 


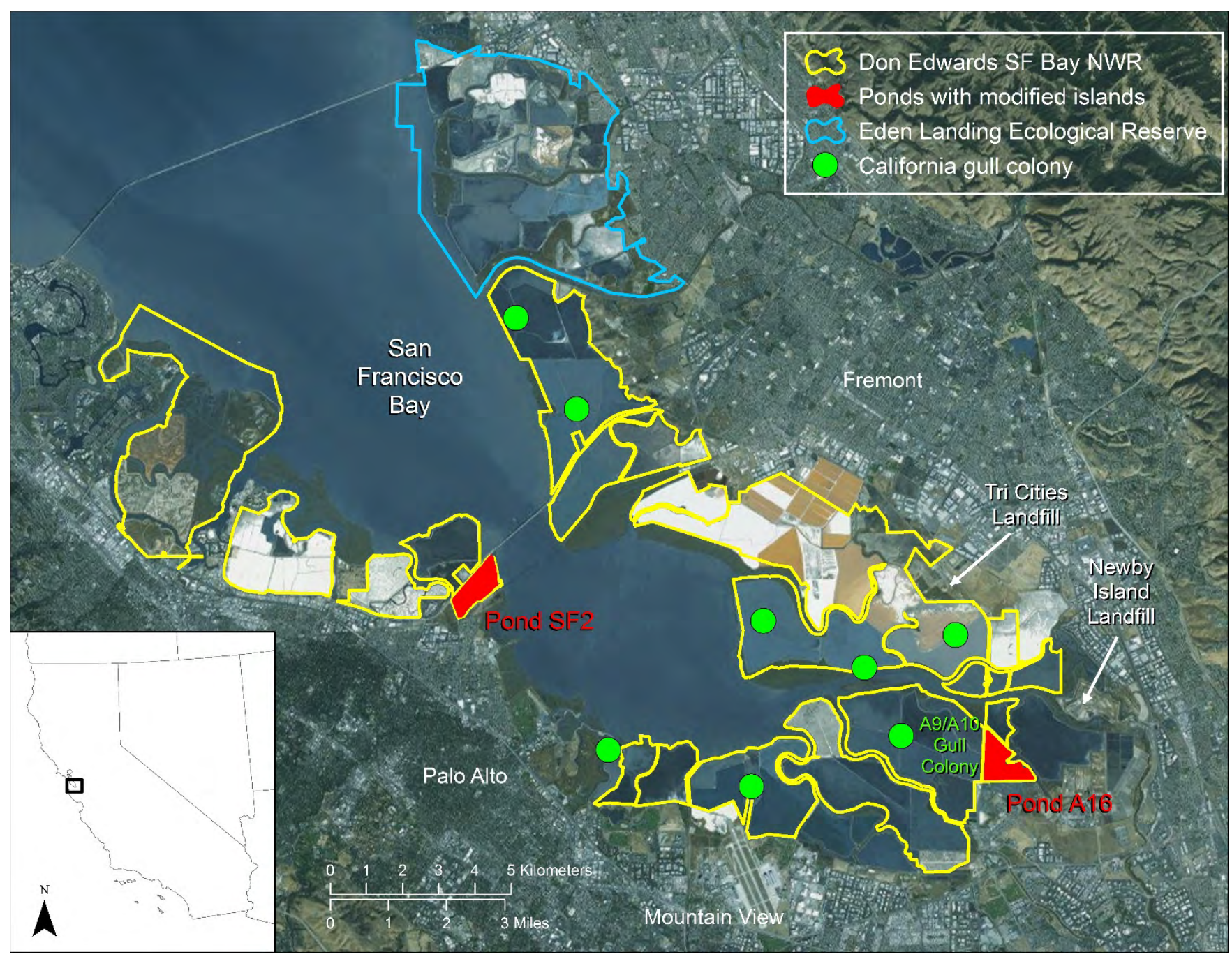

Figure 1. Locations of Ponds A16 and SF2 (red shaded polygons) containing islands modified for Caspian terns and snowy plovers, Don Edwards San Francisco Bay National Wildlife Refuge, California. Green circles indicate California gull breeding colonies. 


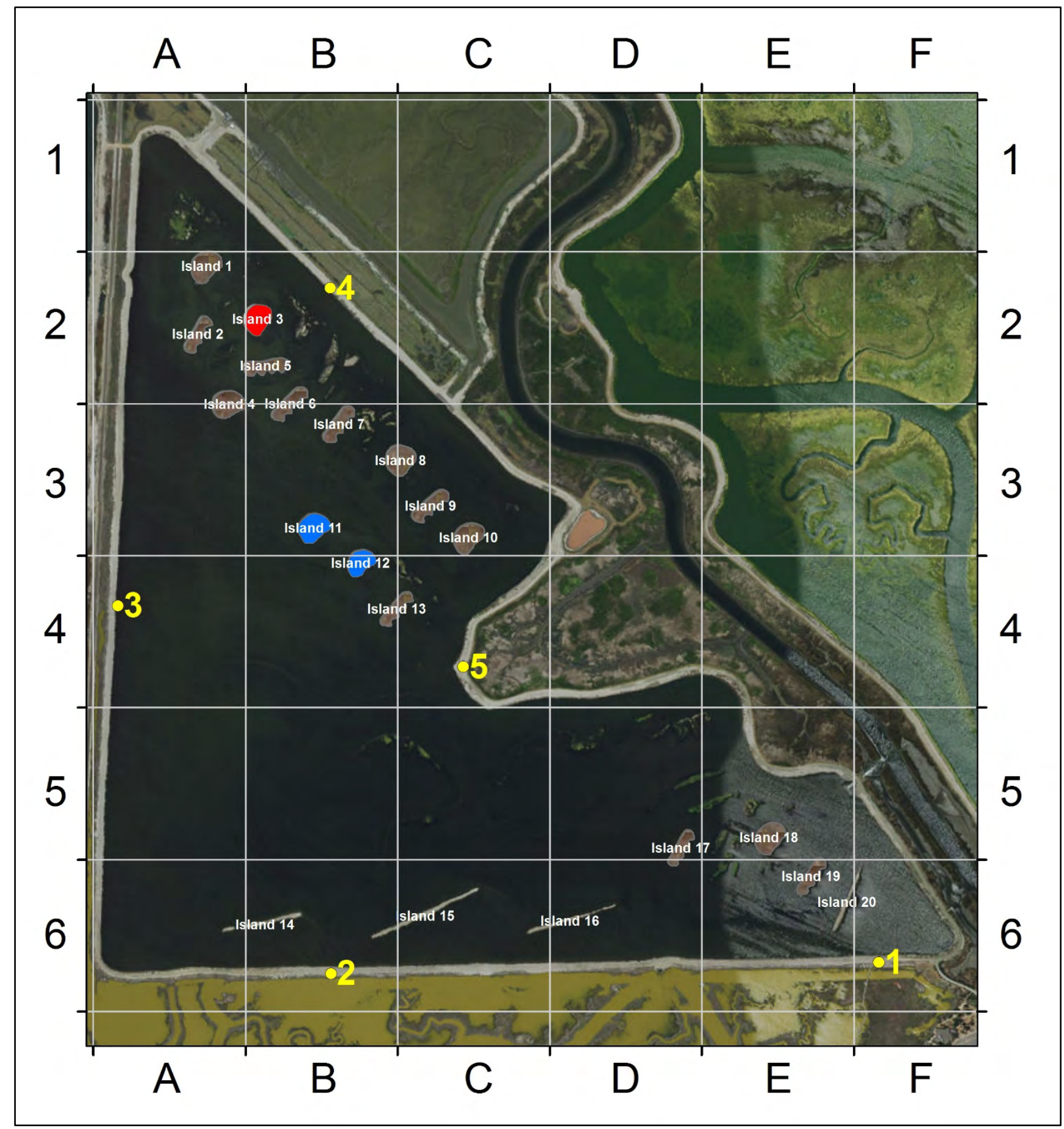

Figure 2. Locations of islands modified for nesting Caspian terns (Islands 11 and 12; shown in blue) and nesting snowy plovers (Island 3; shown in red) in Pond A16, Don Edwards San Francisco Bay National Wildlife Refuge, California. Numbered yellow dots designate vantage points used to count birds in the pond during pond surveys. Square grid cells are 250 by 250 meters. 


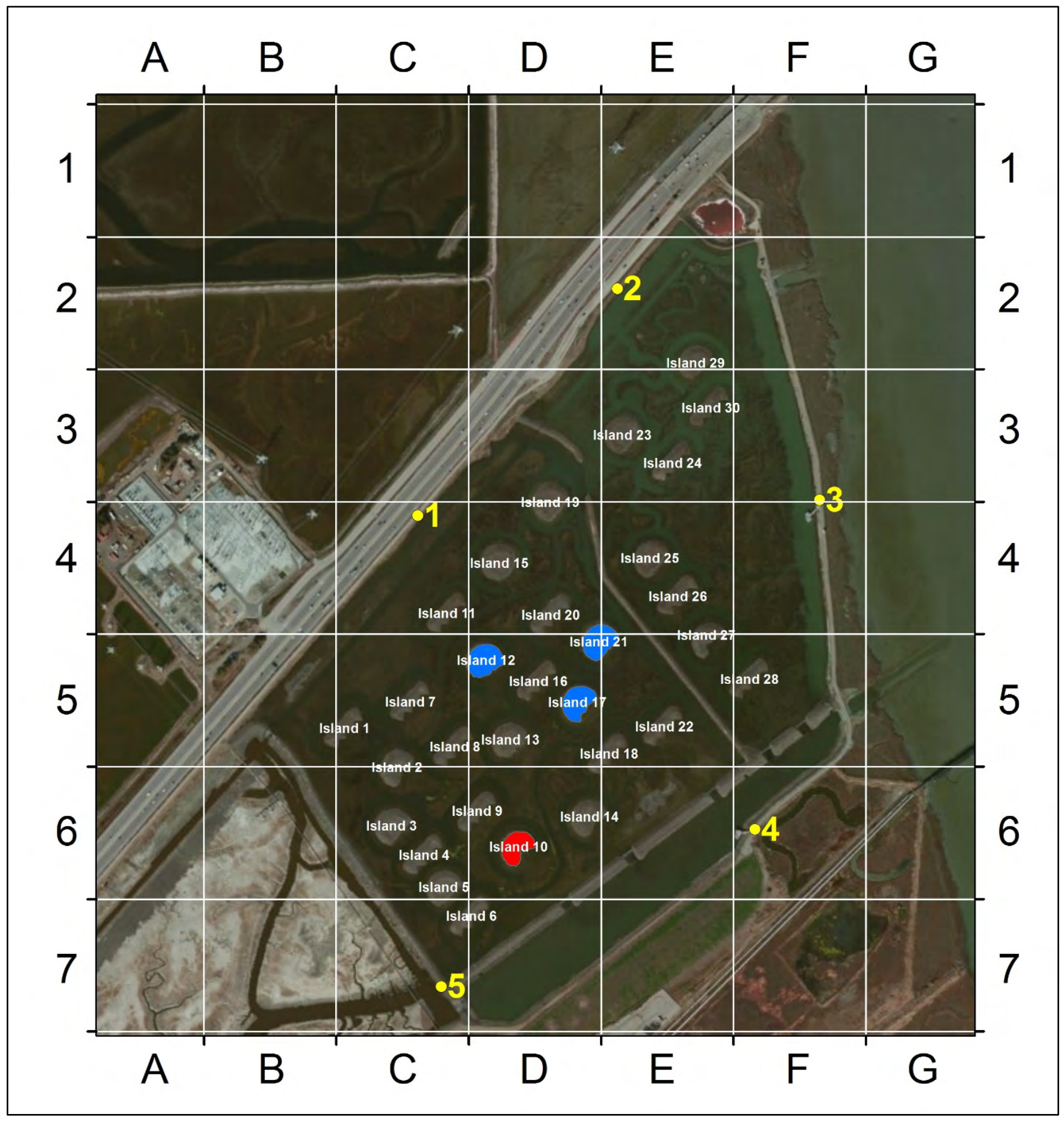

Figure 3. Locations of islands modified for nesting Caspian terns (Islands 12, 17, and 21; shown in blue) and nesting snowy plovers (Island 10; shown in red) in Pond SF2, Don Edwards San Francisco Bay National Wildlife Refuge, California. Numbered yellow dots designate vantage points used to count birds in the pond during pond surveys. Square grid cells are 250 by 250 meters. 


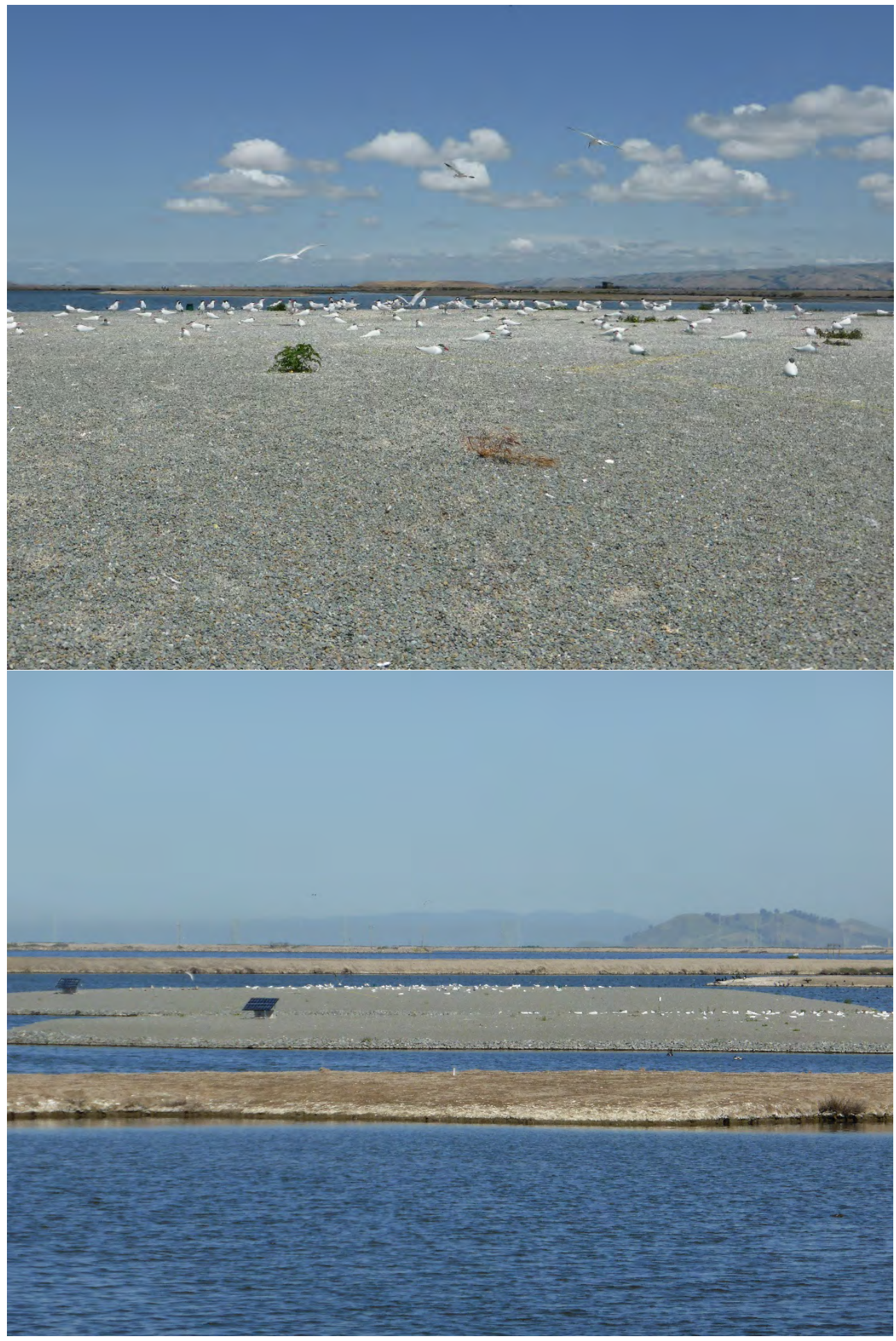

Figure 4. Arrangement of social attraction measures (decoys and call system) for Caspian terns on modified Island 11 (top) and Islands 11 (bottom background) and 12 (bottom foreground) in Pond A16, Don Edwards San Francisco Bay National Wildlife Refuge, California. Top and bottom photographs by Crystal Shore, USGS, May 23 and April 5, 2016, respectively. 

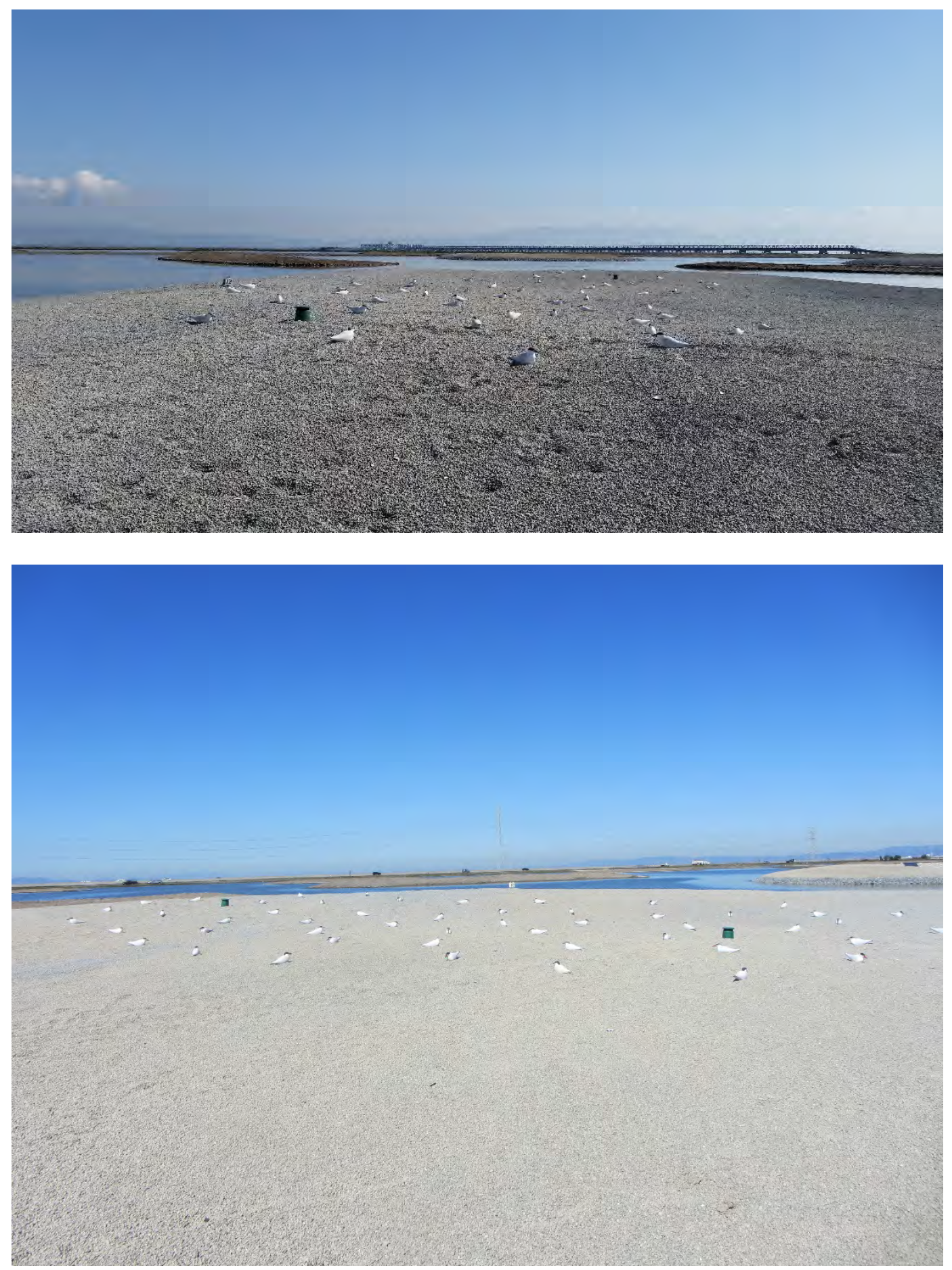

Figure 5. Arrangement of social attraction measures (decoys and call system) for Caspian terns on modified Island 12 (top) and Island 17 (bottom) in Pond SF2, Don Edwards San Francisco Bay National Wildlife Refuge, California. Top photograph by Alex Hartman, USGS, March 3, 2015. Bottom photograph by Kimberly Sawyer, USGS, March 17, 2015. 


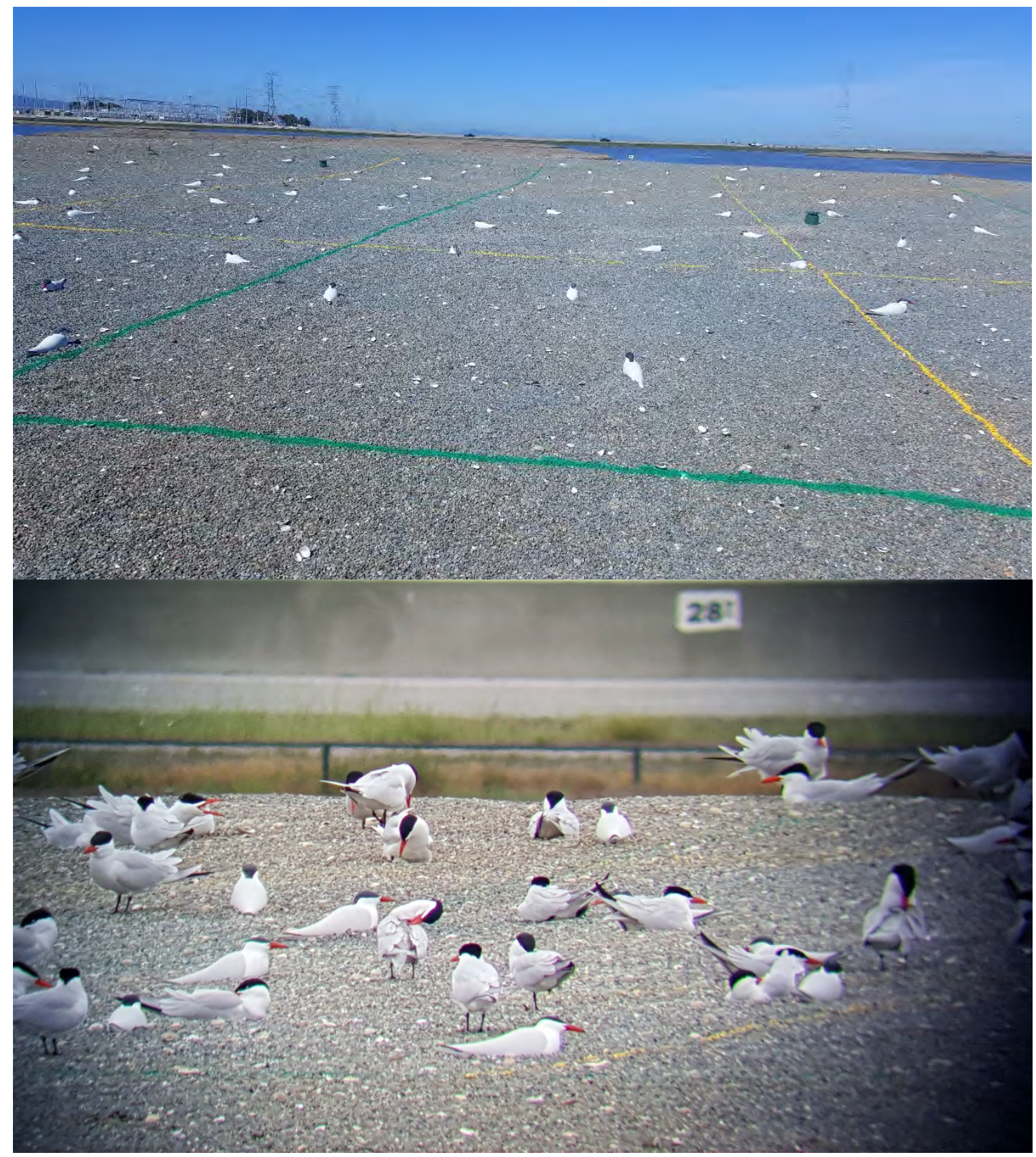

Figure 6. Arrangement of social attraction measures (decoys and call system) for Caspian terns on modified Island 21 in Pond SF2, Don Edwards San Francisco Bay National Wildlife Refuge, California. Top and bottom photographs by Crystal Shore, USGS, March 17 and April 12, 2016, respectively. 


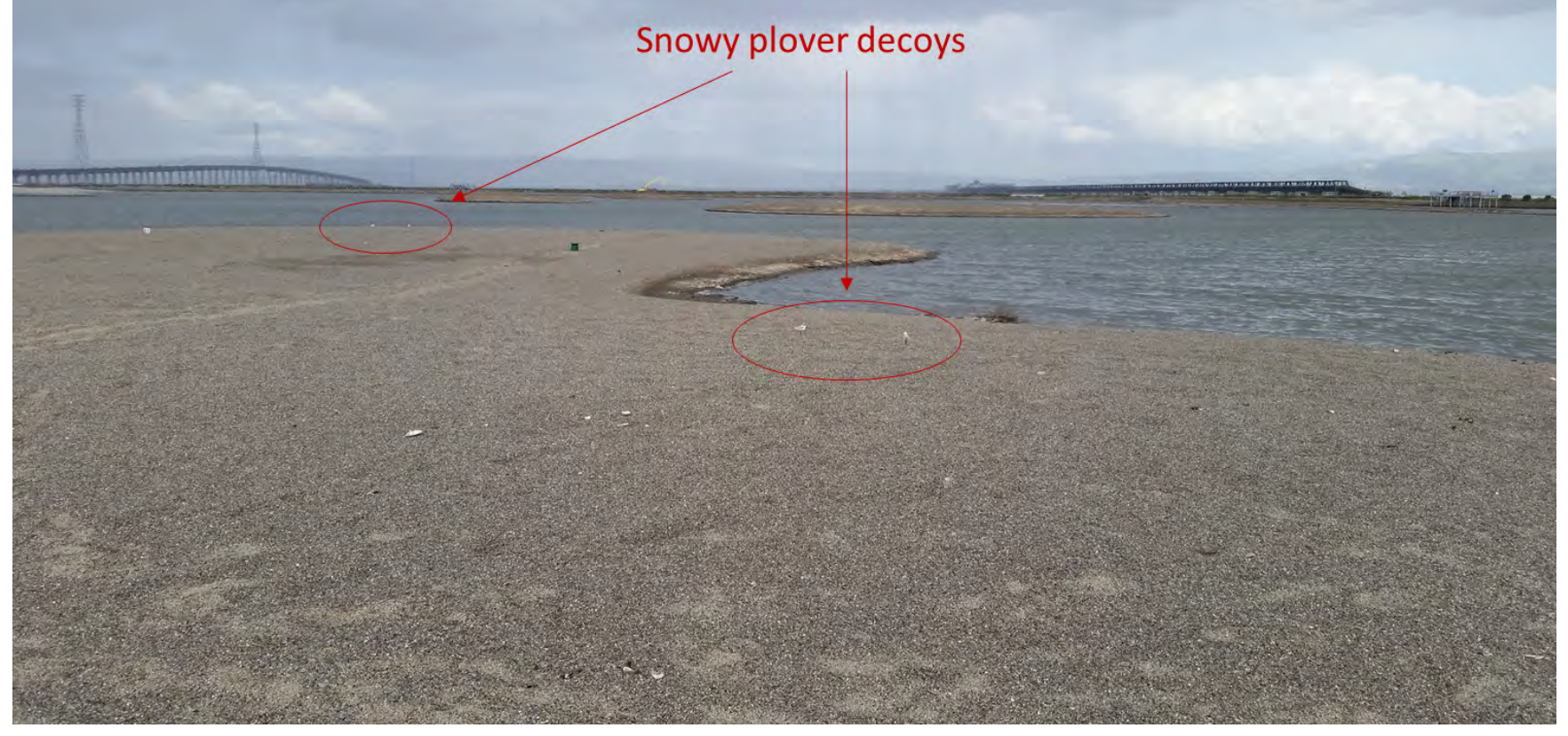

Figure 7. Arrangement of social attraction measures (decoys and call system) for snowy plovers on modified Island 10 in Pond SF2, Don Edwards San Francisco Bay National Wildlife Refuge, California. Photograph by Alex Hartman, USGS, March 2, 2015. 

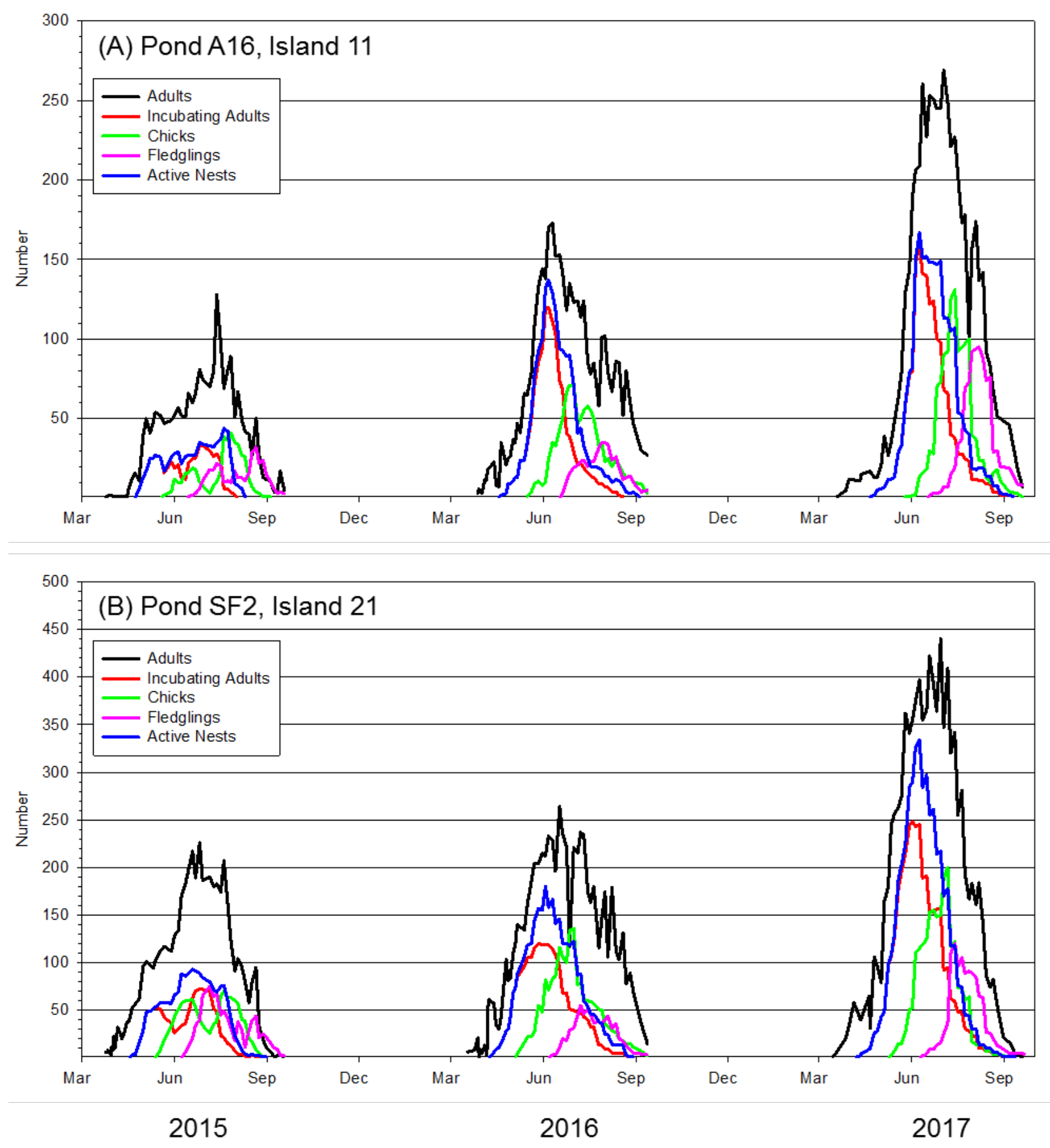

Figure 8. Number of Caspian tern adults, incubating adults, chicks, fledglings, and active nests by date at (A) Pond A16, Island 11; and (B) Pond SF2, Island 21, Don Edwards San Francisco Bay National Wildlife Refuge, California, March-September 2015-17. No Caspian terns nested in Pond A16 or Pond SF2 prior to 2015. 

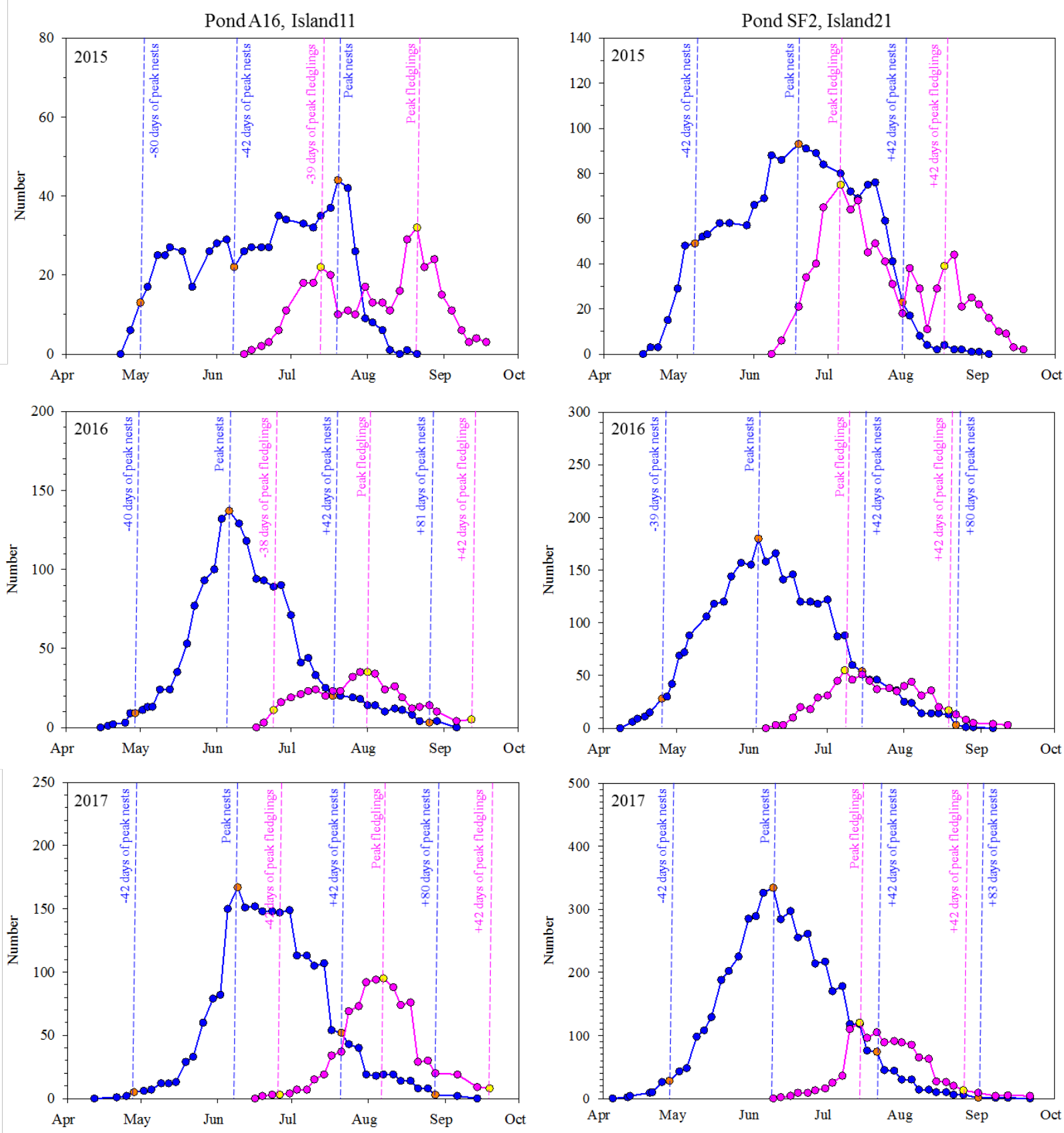

Figure 9. Number of Caspian tern nests (blue lines and circles) and fledglings (pink lines and circles) by date on Island 11 in Pond A16 (left graphs) and Island 21 in Pond SF2 (right graphs) in 2015 (top graphs), 2016 (middle graphs), and 2017 (bottom graphs), Don Edwards San Francisco Bay National Wildlife Refuge, California. Total number of breeding pairs was estimated in each year by summing the peak number of nests and nests observed about 40 days before, about 40 days after, about 80 days before, and about 80 days after the peak (orange circles). Total number of fledglings produced was estimated in each year by summing the peak number of fledglings, and fledglings observed about 40 days before and about 40 days after the peak (yellow circles). 

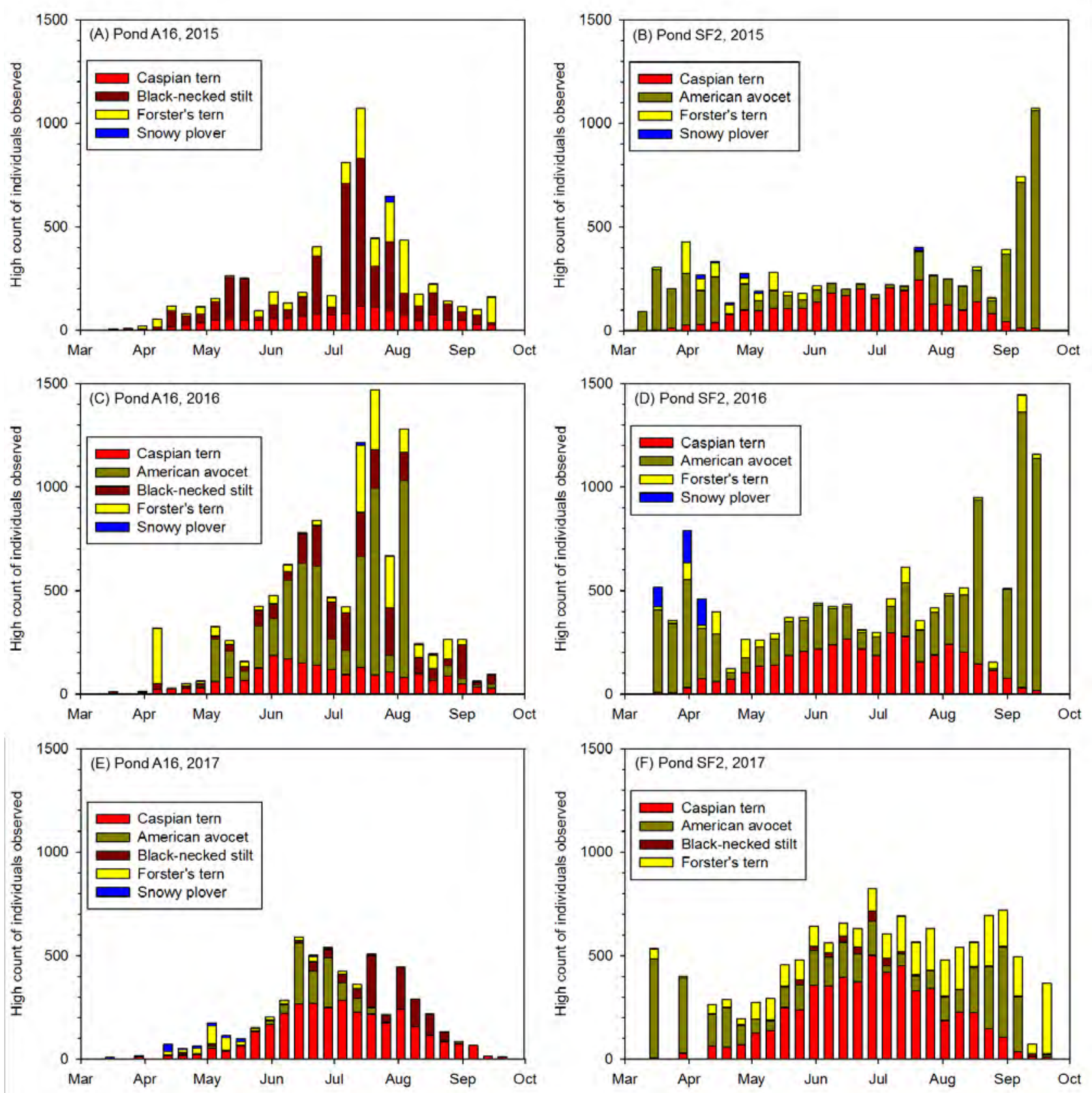

Figure 10. Weekly high counts of individuals of the most abundant nesting waterbird species (excluding California gulls) observed during pond surveys at Ponds A16 (left graphs) and SF2 (right graphs), Don Edwards San Francisco Bay National Wildlife Refuge, California, March-September 2015-17. 

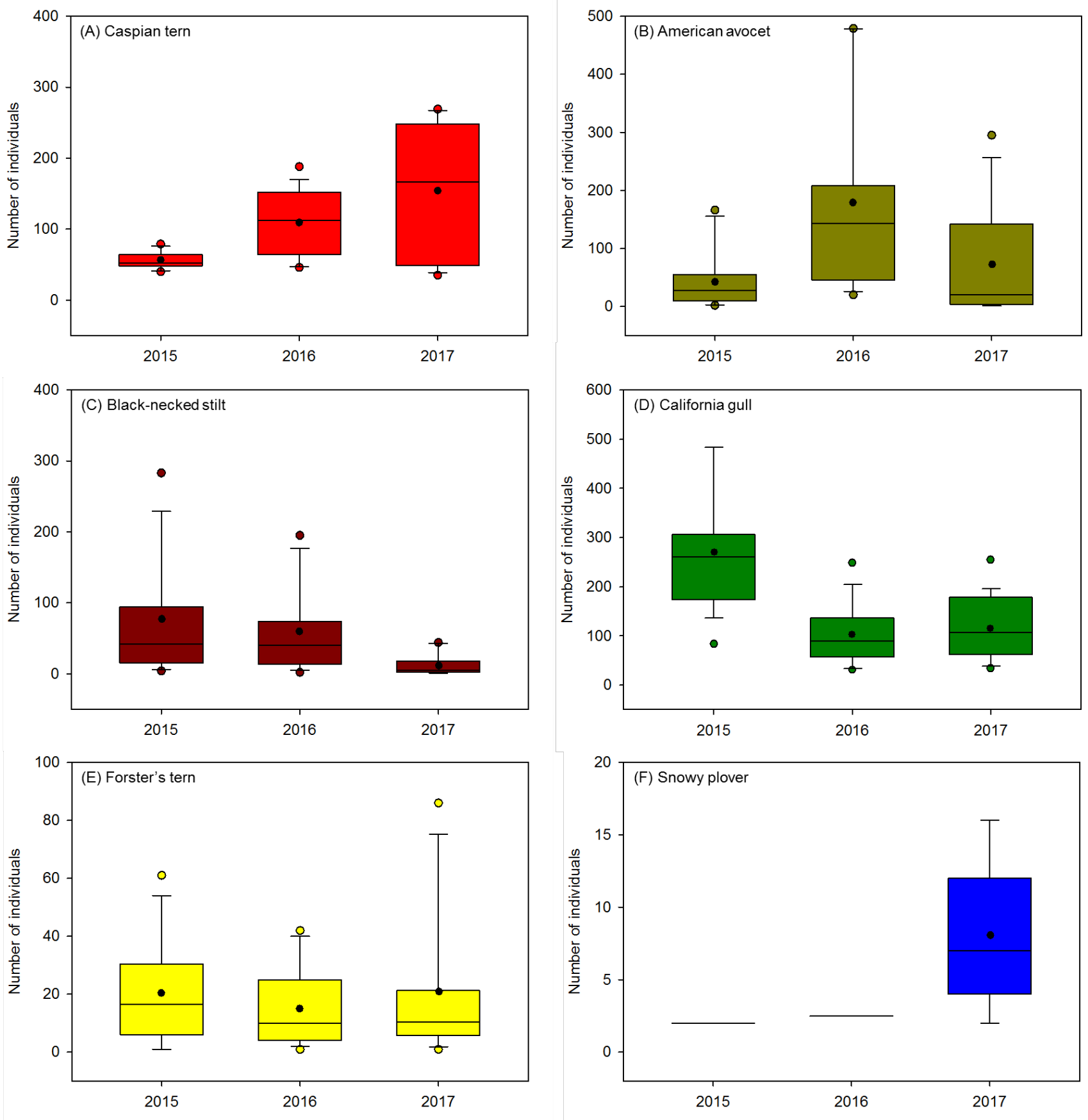

Figure 11. Counts of (A) Caspian terns, (B) American avocets, (C) black-necked stilts, (D) California gulls, (E) Forster's terns, and (F) western snowy plovers at Pond A16, Don Edwards San Francisco Bay National Wildlife Refuge, California, during May-June of 2015-17. Boxplots include the average (solid black circles), median (horizontal lines), 25th and 75th percentiles (bottoms and tops of boxes), 10th and 90th percentiles (error bars), and outlier observations (filled circles). 

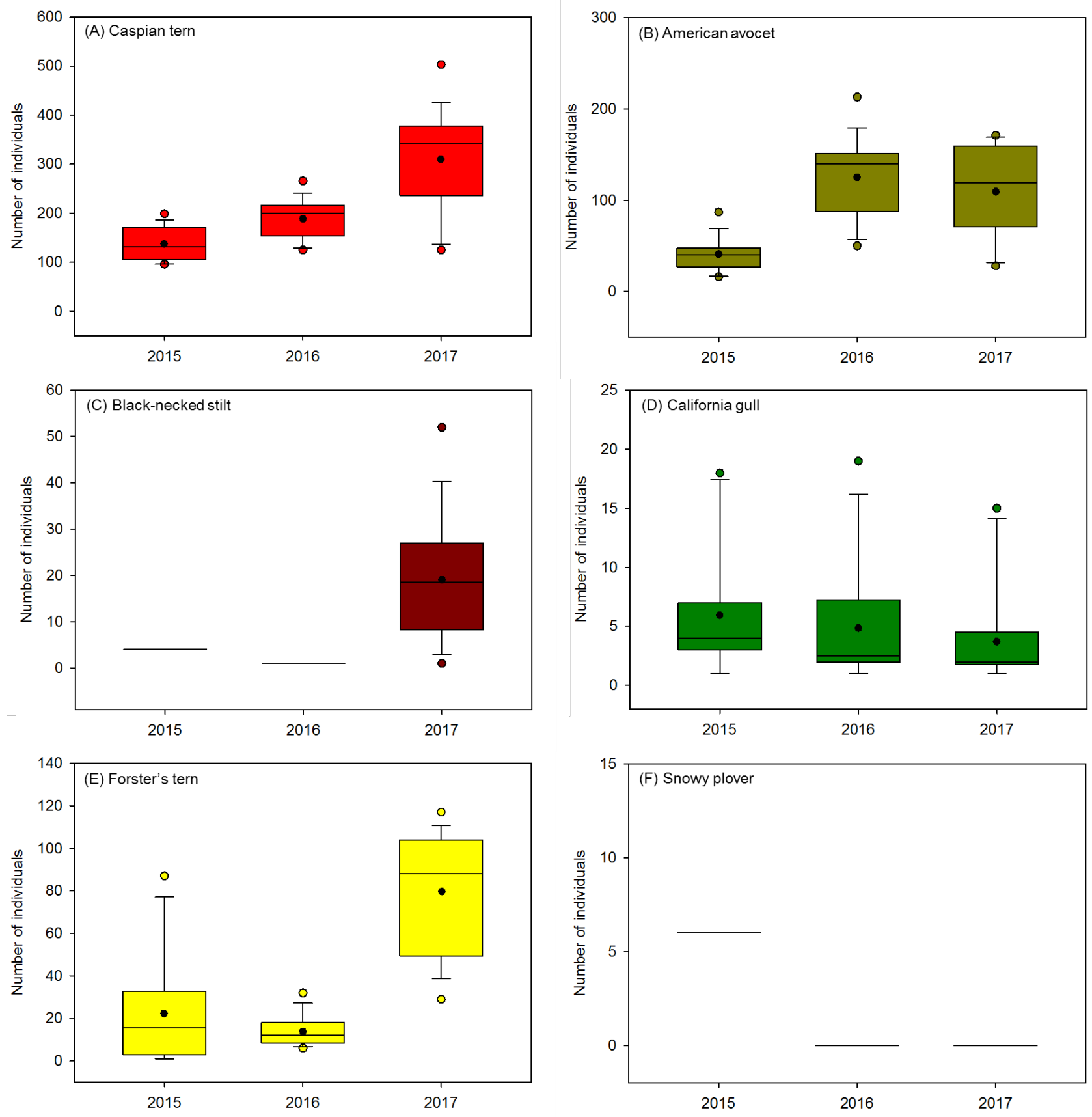

Figure 12. Counts of (A) Caspian terns, (B) American avocets, (C) black-necked stilts, (D) California gulls, (E) Forster's terns, and (F) western snowy plovers at Pond SF2, Don Edwards San Francisco Bay National Wildlife Refuge, California, during May-June of 2015-17. Boxplots include the average (solid black circles), median (horizontal lines), 25th and 75th percentiles (bottoms and tops of boxes), 10th and 90th percentiles (error bars), and outlier observations (filled circles). 
(A) Pond A16

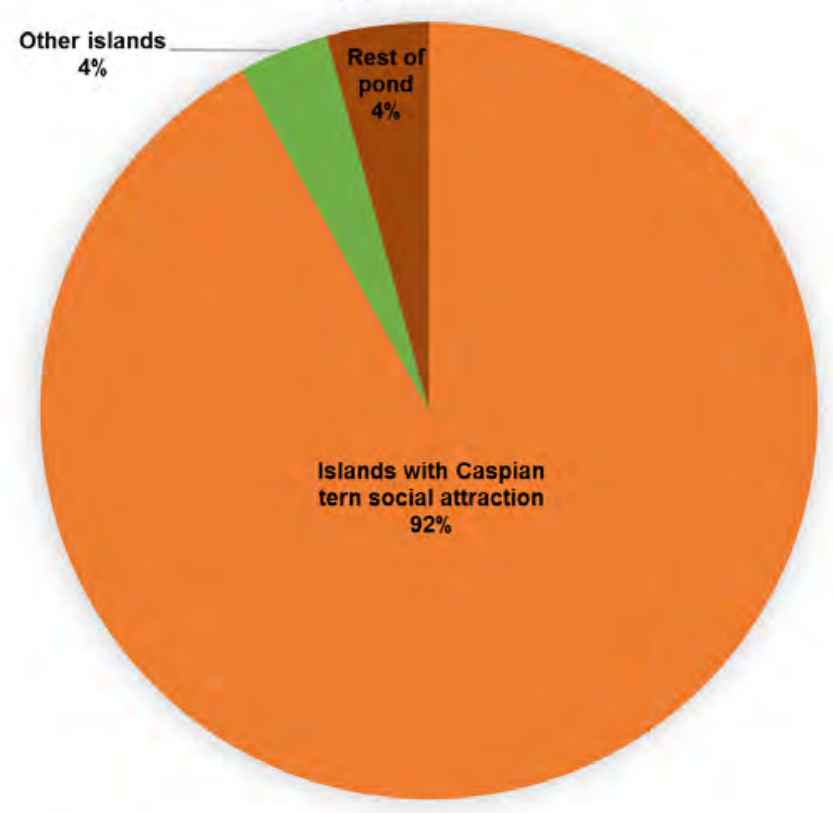

(B) Pond SF2

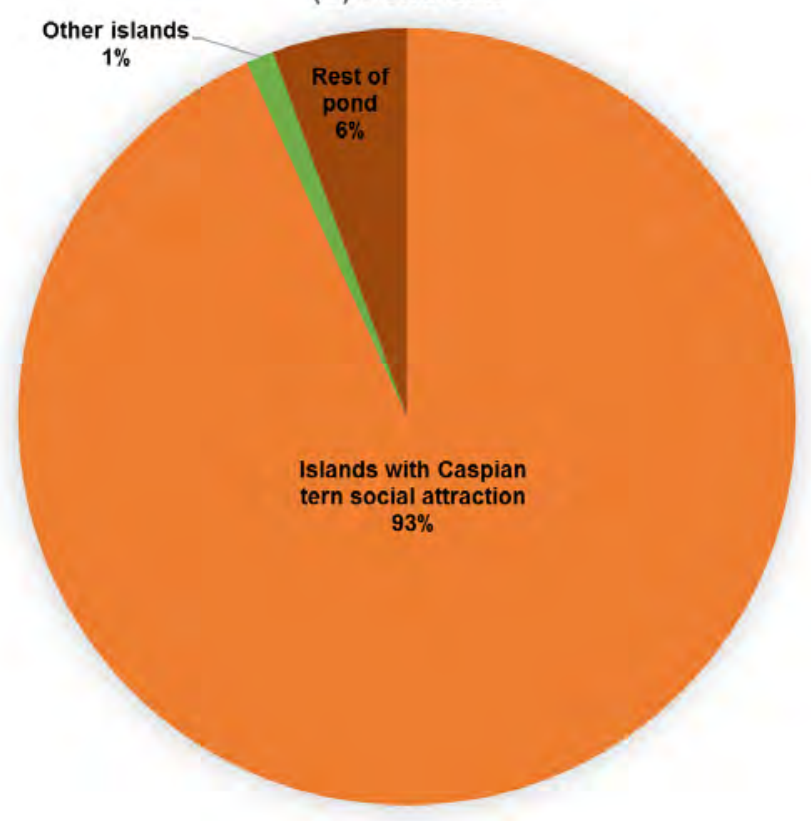

Figure 13. Percentage of Caspian tern observations by location during 166 behavior surveys conducted at Ponds A16 (A) and SF2 (B), Don Edwards San Francisco Bay National Wildlife Refuge, California, March-September 2015-17. 

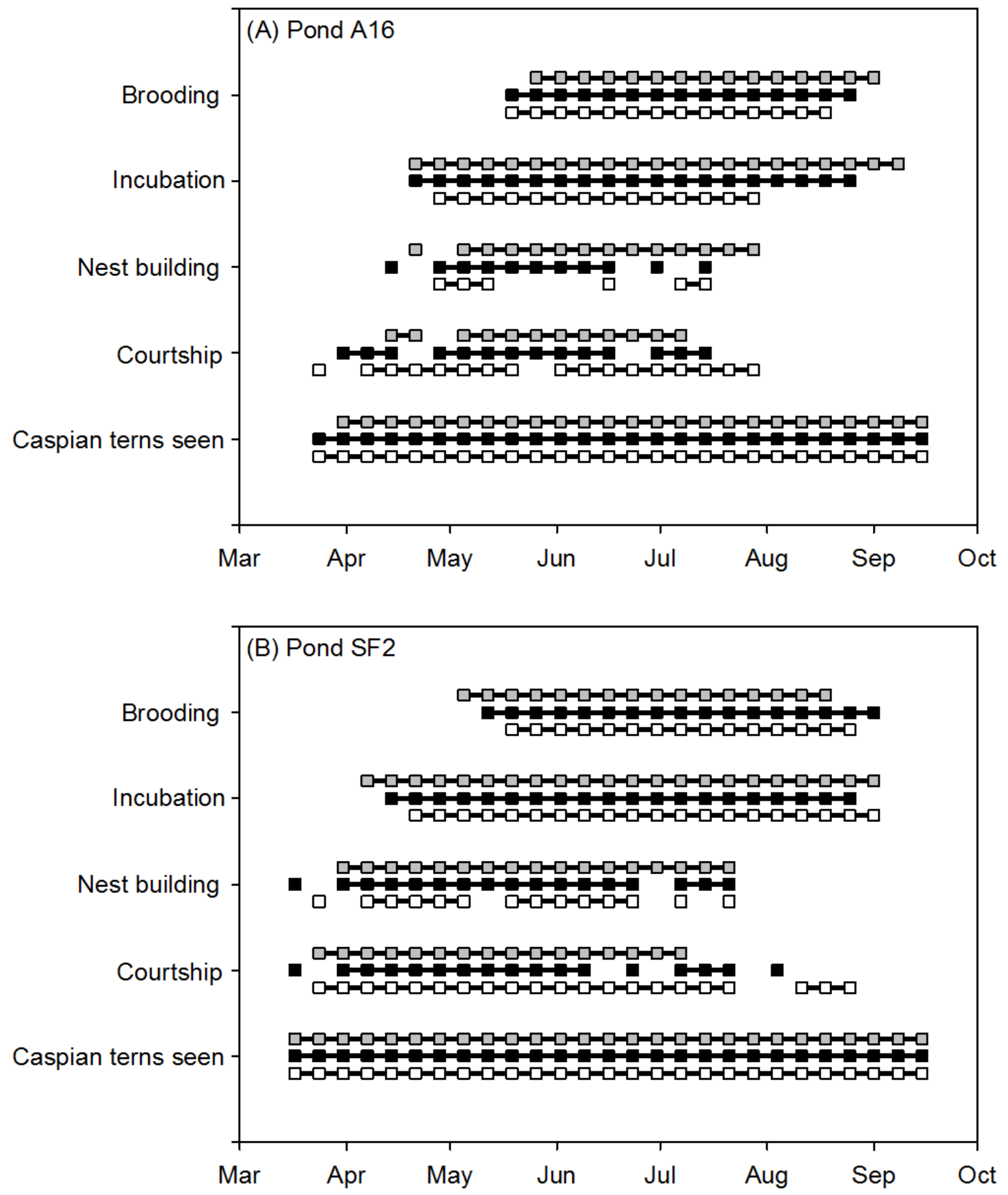

Figure 14. Breeding chronology of Caspian terns based on observed behaviors at Ponds A16 (A) and SF2 (B), Don Edwards San Francisco Bay National Wildlife Refuge, California, in 2015 (white squares), 2016 (black squares), and 2017 (gray squares). Surveys were conducted from March to September of each year. 


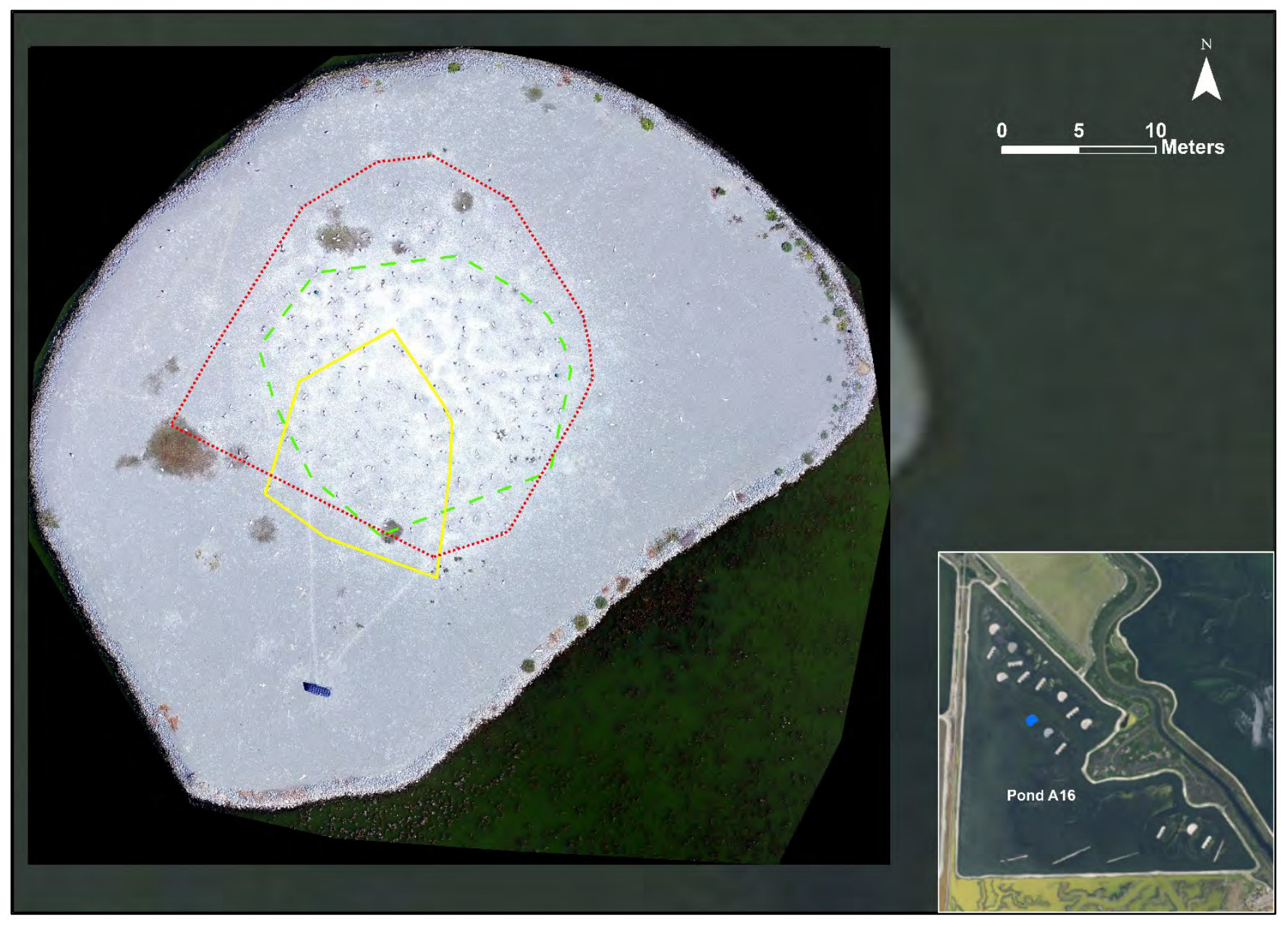

Figure 15. Aerial photograph showing Island 11 modified for Caspian terns in Pond A16, Don Edwards San Francisco Bay National Wildlife Refuge, California. Lines denote Caspian tern colony extents in 2015 (solid yellow), 2016 (dashed green), and 2017 (dotted red). Photograph by Real Time Research, June 21, 2017. 


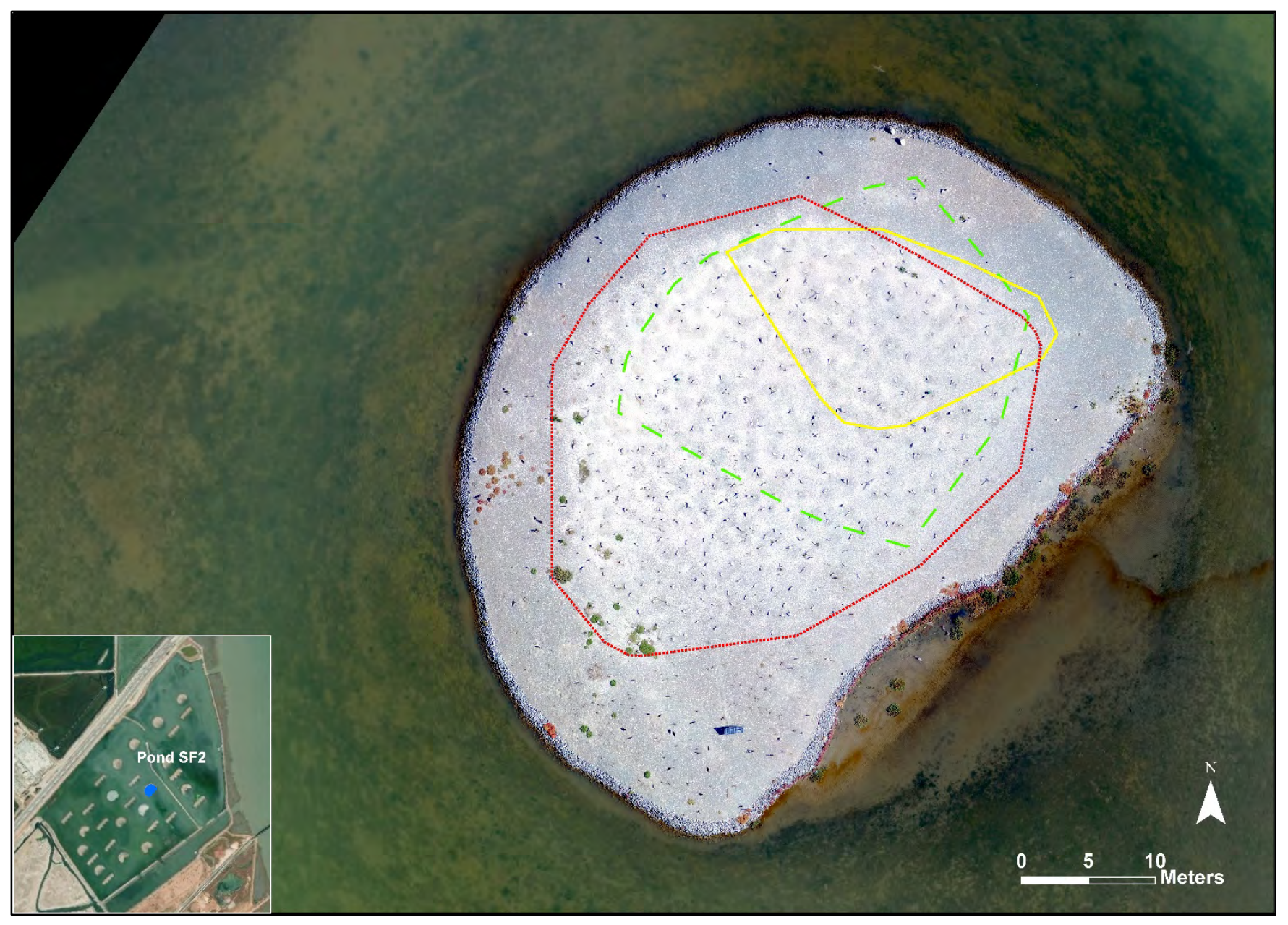

Figure 16. Aerial photograph showing Island 21 modified for Caspian terns in Pond SF2, Don Edwards San Francisco Bay National Wildlife Refuge, California. Lines denote Caspian tern colony extents in 2015 (solid yellow), 2016 (dashed green), and 2017 (dotted red). Photograph by Real Time Research, June 21, 2017. 


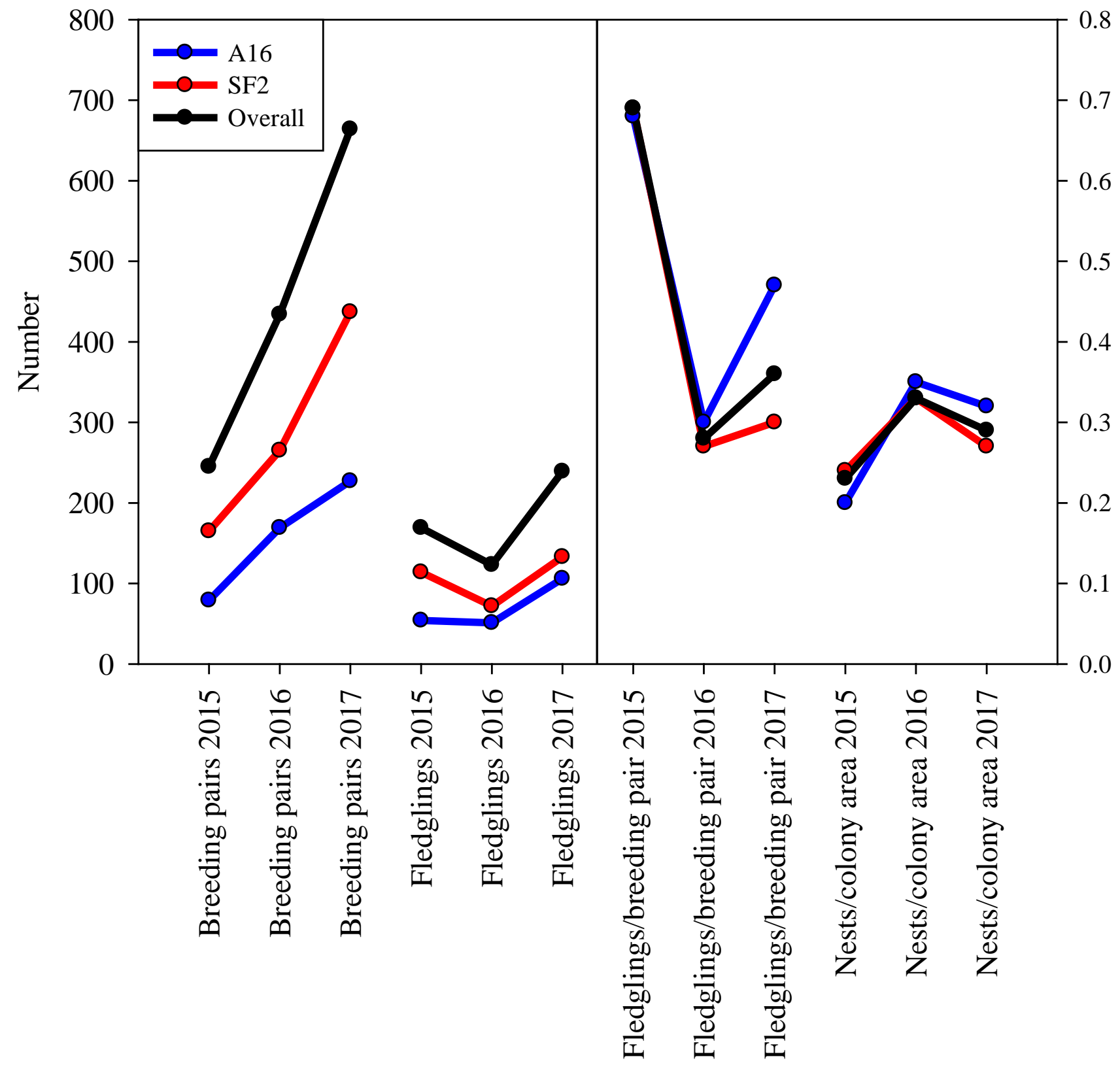

Figure 17. Total number of Caspian tern breeding pairs and fledglings, and the apparent breeding success (fledglings per breeding pair) and apparent nest density (nests per square meter of colony area) at Ponds A16 and SF2, and overall, Don Edwards San Francisco Bay National Wildlife Refuge, California, 2015-17. 
Table 1. Summary of social attraction efforts at three islands in Pond A16 and four islands in Pond SF2, Don Edwards San Francisco Bay National Wildlife Refuge, California, 2015-17.

[Note that the number of decoys varied among years because of manufacturer delivery dates and more decoys becoming available from partner agencies]

\begin{tabular}{|c|c|c|c|c|c|}
\hline Pond & $\begin{array}{l}\text { Island } \\
\text { number }\end{array}$ & Type & $\begin{array}{c}\text { Number of } \\
\text { decoys }\end{array}$ & $\begin{array}{c}\text { Date of decoy and call } \\
\text { system deployment }\end{array}$ & $\begin{array}{c}\text { Date of decoy and call } \\
\text { system retrieval }\end{array}$ \\
\hline \multicolumn{6}{|c|}{2015} \\
\hline A16 & 3 & Snowy plover & 6 & March 6 & September 23 \\
\hline A16 & 11 & Caspian tern & 128 & March 4 & September 23 \\
\hline A16 & 12 & Caspian tern & 58 & March 4 & September 23 \\
\hline SF2 & 10 & Snowy plover & 6 & March 2 & September 22 \\
\hline SF2 & 12 & Caspian tern & 50 & March 3 & September 22 \\
\hline SF2 & 17 & Caspian tern & 51 & March 5 & September 22 \\
\hline $\mathrm{SF} 2$ & 21 & Caspian tern & 104 & March 3 & September 22 \\
\hline \multicolumn{6}{|c|}{2016} \\
\hline A16 & 3 & Snowy plover & 6 & March 2 & August 28 \\
\hline A16 & 11 & Caspian tern & 105 & March 2 & September 19 \\
\hline A16 & 12 & Caspian tern & 105 & March 1 & September 19 \\
\hline SF2 & 10 & Snowy plover & 6 & March 9 & August 4 \\
\hline SF2 & 12 & Caspian tern & 105 & March 8 & September 22 \\
\hline SF2 & 17 & Caspian tern & 105 & March 9 & September 22 \\
\hline $\mathrm{SF} 2$ & 21 & Caspian tern & 105 & March 8 & September 22 \\
\hline \multicolumn{6}{|c|}{2017} \\
\hline A16 & 3 & Snowy plover & 6 & March 9 & September 19 \\
\hline A16 & 11 & Caspian tern & 115 & March 9 & October 2 \\
\hline A16 & 12 & Caspian tern & 115 & March 3 & September 26 \\
\hline SF2 & 10 & Snowy plover & 6 & February 24 & October 11 \\
\hline SF2 & 12 & Caspian tern & 115 & March 1 & September 28 \\
\hline SF2 & 17 & Caspian tern & 115 & February 28 & October 11 \\
\hline SF2 & 21 & Caspian tern & 115 & March 1 & October 4 \\
\hline
\end{tabular}


Table 2. Total number of Caspian terns observed and the number of surveys in which Caspian terns were observed on each island during 166 pond surveys conducted at Ponds A16 and SF2, Don Edwards San Francisco Bay National Wildlife Refuge, California, March-September 2015-17.

[Islands modified for Caspian terns or snowy plovers are in bold type. Total number of surveys were as follows: 62 in 2015, 55 in 2016, and 49 in 2017. -, birds were not observed on island.]

\begin{tabular}{|c|c|c|c|}
\hline \multirow[t]{2}{*}{ Island } & \multicolumn{3}{|c|}{$\begin{array}{l}\text { Total number of Caspian terns observed during all surveys } \\
\text { (number of surveys where Caspian terns observed) }\end{array}$} \\
\hline & 2015 & 2016 & 2017 \\
\hline \multicolumn{4}{|c|}{ Pond A16 } \\
\hline 1 & $4(5)$ & $6(5)$ & - \\
\hline 2 & $5(4)$ & $4(4)$ & $6(3)$ \\
\hline${ }^{1} \mathbf{3}$ & 1 (1) & 1 (1) & - \\
\hline 4 & 38 (18) & 66 (25) & $156(21)$ \\
\hline 5 & $1(1)$ & $5(4)$ & $3(2)$ \\
\hline 6 & $9(6)$ & $15(11)$ & $41(6)$ \\
\hline 7 & $8(7)$ & $12(9)$ & $9(6)$ \\
\hline 8 & 84 (12) & 18 (13) & 7 (5) \\
\hline 9 & $13(8)$ & $7(4)$ & $4(3)$ \\
\hline 10 & $1(1)$ & $1(1)$ & - \\
\hline $2,3 \mathbf{1 1}$ & 1,985 (49) & 3,530 (52) & $5,284(45)$ \\
\hline${ }^{2} 12$ & 85 (16) & $8(7)$ & $68(14)$ \\
\hline 13 & $6(5)$ & $3(3)$ & $3(3)$ \\
\hline 14 & $2(2)$ & $1(1)$ & $5(4)$ \\
\hline 15 & $1(1)$ & $4(4)$ & - \\
\hline 16 & $1(1)$ & $1(1)$ & - \\
\hline 17 & $1(1)$ & - & $9(3)$ \\
\hline 18 & $18(1)$ & $3(2)$ & $12(2)$ \\
\hline 19 & $4(1)$ & $1(1)$ & $12(2)$ \\
\hline 20 & - & $1(1)$ & $1(1)$ \\
\hline \multicolumn{4}{|c|}{ Pond SF2 } \\
\hline 2 & - & - & $1(1)$ \\
\hline 3 & - & - & $1(1)$ \\
\hline 4 & - & $1(1)$ & - \\
\hline 7 & - & $1(1)$ & $2(2)$ \\
\hline 8 & $3(1)$ & - & - \\
\hline 9 & - & $1(1)$ & - \\
\hline${ }^{1} \mathbf{1 0}$ & $3(2)$ & 1 (1) & - \\
\hline${ }^{2} 12$ & $15(10)$ & $2(2)$ & 20 (9) \\
\hline 13 & $1(1)$ & $3(1)$ & - \\
\hline 14 & $3(3)$ & $6(4)$ & $12(5)$ \\
\hline 16 & $2(2)$ & $2(2)$ & $9(3)$ \\
\hline${ }^{2} \mathbf{1 7}$ & $178(43)$ & 211 (29) & $245(31)$ \\
\hline 18 & $14(8)$ & 65 (15) & 15 (10) \\
\hline 19 & - & $18(6)$ & 33 (9) \\
\hline 20 & $21(11)$ & $16(5)$ & $56(11)$ \\
\hline${ }^{2,3} \mathbf{2 1}$ & $4,538(58)$ & $6,469(54)$ & $9,130(49)$ \\
\hline 22 & $14(8)$ & $6(6)$ & $4(2)$ \\
\hline 24 & $10(2)$ & $2(2)$ & $2(1)$ \\
\hline 25 & $2(2)$ & $9(6)$ & $136(13)$ \\
\hline 26 & - & $2(2)$ & $13(5)$ \\
\hline 27 & - & - & $4(3)$ \\
\hline 28 & - & - & $1(1)$ \\
\hline 29 & $1(1)$ & - & $1(1)$ \\
\hline 30 & - & $2(1)$ & - \\
\hline
\end{tabular}

${ }^{1}$ Denotes islands with social attractions for snowy plovers.

${ }^{2}$ Denotes islands with social attractions for Caspian terns.

${ }^{3}$ Denotes islands where Caspian terns nested. 
Table 3. Breeding metrics on seven modified islands with social attraction measures for Caspian terns and snowy plovers in Ponds A16 and SF2, Don Edwards San Francisco Bay National Wildlife Refuge, California, 2015-17.

[Dash (-) denotes that the calculation is not possible. Numbers in parentheses denote the percentage of change from the previous year (\%), where light gray shading indicates an increase and dark gray shading indicates a decrease. Peak number of nests: High count or peak number of nests over the nesting season. Estimated number of breeding pairs: Calculated as the high count or peak number of nests, plus the number of nests active 40 days prior to, 40 days after, 80 days prior to, and 80 days after, the peak. See report section, "Methods" for details. Peak number of fledglings: High count or peak number of fledglings over the nesting season.

Estimated number of chicks fledged: Calculated as the high count or peak number of fledglings, plus the number of fledglings 40 days prior to and 40 days after the peak. Breeding success: Calculated by dividing the number of chicks fledged by the number of breeding pairs. Apparent nest density (nests/island $\mathbf{m}^{2}$ ): Calculated by dividing the number of nests on the island at the time the aerial photograph of the colony was taken by the total island area. Apparent nest density (nests/colony $\mathbf{m}^{2}$ ): Calculated by dividing the number of nests on the island at the time the aerial photograph of the colony was taken by the colony area. $\mathrm{m}^{2}$, square meter]

\begin{tabular}{|c|c|c|c|c|c|c|c|c|c|c|c|}
\hline \multirow[b]{2}{*}{ Year(s) } & \multirow[b]{2}{*}{ Pond } & \multirow[b]{2}{*}{ Island } & \multirow{2}{*}{$\begin{array}{l}\text { Peak number } \\
\text { of nests }\end{array}$} & \multirow{2}{*}{$\begin{array}{c}\text { Estimated } \\
\text { number of } \\
\text { breeding } \\
\text { pairs }\end{array}$} & \multirow{2}{*}{$\begin{array}{l}\text { Peak number } \\
\text { of fledglings }\end{array}$} & \multirow{2}{*}{$\begin{array}{c}\text { Estimated } \\
\text { number of } \\
\text { chicks } \\
\text { fledged }\end{array}$} & \multirow{2}{*}{$\begin{array}{l}\text { Breeding } \\
\text { success } \\
\text { (fledglings/ } \\
\text { breeding pair) }\end{array}$} & \multirow{2}{*}{$\begin{array}{c}\text { Island } \\
\text { gravel } \\
\text { area }\left(\mathrm{m}^{2}\right)\end{array}$} & \multirow{2}{*}{$\begin{array}{l}\text { Colony area } \\
\qquad\left(\mathrm{m}^{2}\right)\end{array}$} & \multicolumn{2}{|c|}{ Apparent nest density } \\
\hline & & & & & & & & & & (nests/island m²) & (nests/colony $\mathrm{m}^{2}$ ) \\
\hline & \multicolumn{11}{|c|}{ Caspian tern } \\
\hline 2015 & A16 & 11 & ${ }^{1} 73$ & 79 & ${ }^{2} 54$ & 54 & 0.68 & 1,603 & 130 & 0.02 & 0.20 \\
\hline 2015 & A16 & 12 & 0 & 0 & 0 & 0 & - & 1,247 & - & - & - \\
\hline 2015 & SF2 & 12 & 0 & 0 & 0 & 0 & - & 1,841 & - & - & - \\
\hline 2015 & SF2 & 17 & 1 & 1 & 1 & 1 & 1.00 & 1,518 & - & 0.001 & - \\
\hline 2015 & SF2 & 21 & ${ }^{1} 150$ & 165 & ${ }^{2} 119$ & 114 & 0.69 & 1,693 & 236 & 0.03 & 0.24 \\
\hline 2015 & TOTAL & & 224 & 245 & 174 & 169 & 0.69 & 7,903 & 366 & 0.03 & 0.23 \\
\hline 2016 & A16 & 11 & $137(+88 \%)$ & $169(+114 \%)$ & $35(-35 \%)$ & $51(-6 \%)$ & $0.30(-56 \%)$ & 1,603 & $266(+105 \%)$ & $0.06(+258 \%)$ & $0.35(+75 \%)$ \\
\hline 2016 & A16 & 12 & 0 & 0 & 0 & 0 & - & 1,247 & - & - & - \\
\hline 2016 & SF2 & 12 & 0 & 0 & 0 & 0 & - & 1,841 & - & - & - \\
\hline 2016 & SF2 & 17 & 0 & 0 & 0 & 0 & - & 1,518 & - & - & - \\
\hline 2016 & SF2 & 21 & $180(+20 \%)$ & $265(+61 \%)$ & $55(-54 \%)$ & $72(-37 \%)$ & $0.27(-61 \%)$ & 1,693 & $481(+104 \%)$ & $0.09(+175 \%)$ & $0.22(+35 \%)$ \\
\hline 2016 & TOTAL & & $317(+42 \%)$ & $434(+77 \%)$ & $90(-48 \%)$ & $123(-27 \%)$ & $0.28(-59 \%)$ & 7,903 & $747(+104 \%)$ & $0.08(+201 \%)$ & $0.33(+48 \%)$ \\
\hline
\end{tabular}




\begin{tabular}{|c|c|c|c|c|c|c|c|c|c|c|c|}
\hline \multirow[b]{2}{*}{ Year(s) } & \multirow[b]{2}{*}{ Pond } & \multirow[b]{2}{*}{ Island } & \multirow{2}{*}{$\begin{array}{l}\text { Peak number } \\
\text { of nests }\end{array}$} & \multirow{2}{*}{$\begin{array}{c}\text { Estimated } \\
\text { number of } \\
\text { breeding } \\
\text { pairs }\end{array}$} & \multirow{2}{*}{$\begin{array}{l}\text { Peak number } \\
\text { of fledglings }\end{array}$} & \multirow{2}{*}{$\begin{array}{l}\text { Estimated } \\
\text { number of } \\
\text { chicks } \\
\text { fledged }\end{array}$} & \multirow{2}{*}{$\begin{array}{l}\text { Breeding } \\
\text { success } \\
\text { (fledglings/ } \\
\text { breeding pair) }\end{array}$} & \multirow{2}{*}{$\begin{array}{l}\text { Island } \\
\text { gravel } \\
\text { area }\left(\mathrm{m}^{2}\right)\end{array}$} & \multirow{2}{*}{$\begin{array}{l}\text { Colony area } \\
\qquad\left(\mathrm{m}^{2}\right)\end{array}$} & \multicolumn{2}{|c|}{ Apparent nest density } \\
\hline & & & & & & & & & & (nests/island m²) & (nests/colony $\mathrm{m}^{2}$ ) \\
\hline & \multicolumn{11}{|c|}{ Caspian tern (Continued) } \\
\hline 2017 & A16 & 11 & $167(+22 \%)$ & $227(+34 \%)$ & $95(+171 \%)$ & $106(+108 \%)$ & $0.47(+55 \%)$ & 1,603 & $460(+73 \%)$ & $0.09(+59 \%)$ & $0.32(-8 \%)$ \\
\hline 2017 & A16 & 12 & 0 & 0 & 0 & 0 & - & 1,247 & - & - & - \\
\hline 2017 & SF2 & 12 & 0 & 0 & 0 & 0 & - & 1,841 & - & - & - \\
\hline 2017 & SF2 & 17 & 0 & 0 & 0 & 0 & - & 1,518 & - & - & - \\
\hline 2017 & SF2 & 21 & $334(+86 \%)$ & $437(+65 \%)$ & $120(+118 \%)$ & $133(+85 \%)$ & $0.30(+12 \%)$ & 1,693 & $934(+94 \%)$ & $0.15(+62 \%)$ & $0.27(-16 \%)$ \\
\hline \multirow[t]{2}{*}{2017} & TOTAL & & $501(+58 \%)$ & $664(+53 \%)$ & $215(+139 \%)$ & $239(+94 \%)$ & $0.36(+27 \%)$ & 7,903 & $1,394(+87 \%)$ & $0.12(+61 \%)$ & $0.29(-14 \%)$ \\
\hline & \multicolumn{11}{|c|}{ Snowy plover } \\
\hline 2015-17 & A16 & 3 & 0 & 0 & 0 & 0 & - & 1,318 & - & - & - \\
\hline 2015-17 & SF2 & 10 & 0 & 0 & 0 & 0 & - & 1,420 & - & - & - \\
\hline 2015-17 & TOTAL & & 0 & 0 & 0 & 0 & - & 2,738 & - & - & - \\
\hline
\end{tabular}

${ }^{1}$ In 2015, the number of Caspian tern nests under incubation had a bimodal distribution with 2 distinct peaks. Therefore, we summed the high count of nests from these two peaks to estimate the peak number of nests.

${ }^{2}$ In 2015, the number of Caspian fledglings had a bimodal distribution with 2 distinct peaks. Therefore, we summed the high count from these two peaks to estimate the peak number of fledglings. 
Table 4. Sightings of 52 color-banded Caspian terns at Ponds A16 and SF2, Don Edwards San Francisco Bay National Wildlife Refuge, California, 2015-17.

[Banding and past breeding information provided by Kirsten Bixler and Yasuko Suzuki (Oregon State University, written commun., November 11, 2017). Tern: 2, 9, 35, and 38 were unidentifiable because of band loss. Each tern was banded on its left leg with a color band combination, and on its right leg with either a color band combination or a single alphanumeric band. A dash (-) indicates that an individual did not have a particular band type. An X denotes a missing band or unread alphanumeric code]

\begin{tabular}{|c|c|c|c|c|c|c|c|c|c|c|c|c|c|c|c|}
\hline \multirow[b]{2}{*}{ Tern } & \multirow[b]{2}{*}{ Year(s) } & \multicolumn{3}{|c|}{ Left leg } & \multicolumn{6}{|c|}{ Right leg } & \multirow[b]{2}{*}{$\begin{array}{l}\text { Pondl } \\
\text { island }\end{array}$} & \multirow[b]{2}{*}{$\begin{array}{c}\text { Breeding } \\
\text { behavior(s) } \\
\text { observed? }\end{array}$} & \multirow[b]{2}{*}{$\begin{array}{l}\text { Banding } \\
\text { location }\end{array}$} & \multirow[b]{2}{*}{$\begin{array}{l}\text { Banding } \\
\text { year }\end{array}$} & \multirow[b]{2}{*}{$\begin{array}{l}\text { Age at } \\
\text { banding }\end{array}$} \\
\hline & & Top & Middle & Bottom & Top & Middle & Bottom & $\begin{array}{l}\text { Band } \\
\text { color }\end{array}$ & $\begin{array}{l}\text { Code } \\
\text { color }\end{array}$ & $\begin{array}{l}\text { Alpha- } \\
\text { numeric } \\
\text { code }\end{array}$ & & & & & \\
\hline 1 & 2015 & $\begin{array}{l}\text { Light } \\
\text { blue }\end{array}$ & $\begin{array}{l}\text { Light } \\
\text { blue }\end{array}$ & Light blue & $\begin{array}{c}\text { Dark } \\
\text { blue }\end{array}$ & White & Metal & - & - & - & SF2/21 & No & Brooks Island & 2005 & Chick \\
\hline 2 & 2015 & Orange & Orange & $\mathrm{X}$ & $\begin{array}{l}\text { Light } \\
\text { blue }\end{array}$ & White & Metal & - & - & - & SF2 & No & Unknown & Unknown & Unknown \\
\hline 3 & 2015 & Orange & $\begin{array}{l}\text { Light } \\
\text { blue }\end{array}$ & Metal & - & - & - & Yellow & White & XX95 & SF2/21 & No & $\begin{array}{l}\text { East Sand } \\
\text { Island }\end{array}$ & 2006 & Chick \\
\hline 4 & $\begin{array}{l}2015, \\
2017\end{array}$ & Red & Orange & Metal & - & - & - & Yellow & Black & C379 & SF2 & Yes & Brooks Island & 2008 & Adult \\
\hline 5 & 2015 & $\begin{array}{l}\text { Light } \\
\text { blue }\end{array}$ & Green & Metal & - & - & - & Yellow & Black & C073 & SF2 & No & $\begin{array}{c}\text { East Sand } \\
\text { Island }\end{array}$ & 2007 & Chick \\
\hline 6 & 2016 & Red & Orange & $\begin{array}{l}\text { Dark } \\
\text { green }\end{array}$ & Yellow & $\begin{array}{l}\text { Light } \\
\text { green }\end{array}$ & Metal & - & - & - & A16/11 & No & $\begin{array}{l}\text { East Sand } \\
\text { Island }\end{array}$ & 2004 & Chick \\
\hline 7 & $\begin{array}{l}2016, \\
2017\end{array}$ & Orange & $\begin{array}{l}\text { Dark } \\
\text { blue }\end{array}$ & Metal & - & - & - & Yellow & Black & J677 & A16/11 & Yes & $\begin{array}{c}\text { East Sand } \\
\text { Island }\end{array}$ & 2010 & Chick \\
\hline 8 & $\begin{array}{r}2016, \\
2017\end{array}$ & $\begin{array}{l}\text { Dark } \\
\text { green }\end{array}$ & Yellow & Metal & - & - & - & Yellow & Black & K400 & A16/11 & No & Sheepy Lake & 2012 & Chick \\
\hline 9 & 2016 & $\mathrm{X}$ & Yellow & Orange & $\mathrm{X}$ & Metal & $\begin{array}{l}\text { Dark } \\
\text { green }\end{array}$ & - & - & - & SF2/21 & No & Unknown & Unknown & Unknown \\
\hline 10 & 2016 & $\begin{array}{c}\text { Dark } \\
\text { blue }\end{array}$ & Orange & White & $\begin{array}{l}\text { Light } \\
\text { green }\end{array}$ & Metal & White & - & - & - & SF2/21 & No & Knight Island & 2003 & Chick \\
\hline 11 & $\begin{array}{l}\text { 2016, } \\
2017\end{array}$ & $\begin{array}{c}\text { Dark } \\
\text { blue }\end{array}$ & $\begin{array}{c}\text { Dark } \\
\text { blue }\end{array}$ & $\begin{array}{c}\text { Dark } \\
\text { blue }\end{array}$ & $\begin{array}{l}\text { Dark } \\
\text { green }\end{array}$ & $\begin{array}{l}\text { Light } \\
\text { blue }\end{array}$ & Metal & - & - & - & SF2/21 & Yes & Brooks Island & 2005 & Chick \\
\hline 12 & $\begin{array}{r}2016, \\
2017\end{array}$ & Red & $\begin{array}{l}\text { Dark } \\
\text { blue }\end{array}$ & Yellow & Yellow & White & Metal & - & - & - & SF2/21 & Yes & Brooks Island & 2004 & Chick \\
\hline 13 & $\begin{array}{r}2016, \\
2017\end{array}$ & Orange & $\begin{array}{l}\text { Light } \\
\text { green }\end{array}$ & $\begin{array}{l}\text { Dark } \\
\text { blue }\end{array}$ & Yellow & White & Metal & - & - & - & SF2/21 & Yes & Brooks Island & 2004 & Chick \\
\hline 14 & $\begin{array}{r}2016, \\
2017 \\
\end{array}$ & \begin{tabular}{|c} 
Dark \\
blue
\end{tabular} & $\begin{array}{l}\text { Light } \\
\text { green }\end{array}$ & Yellow & \begin{tabular}{|c} 
Dark \\
green
\end{tabular} & $\begin{array}{l}\text { Light } \\
\text { blue }\end{array}$ & Metal & - & - & - & $\mathrm{SF} 2 / 21$ & No & Brooks Island & 2005 & Chick \\
\hline
\end{tabular}




\begin{tabular}{|c|c|c|c|c|c|c|c|c|c|c|c|c|c|c|c|}
\hline \multirow[b]{2}{*}{ Tern } & \multirow[b]{2}{*}{ Year(s) } & \multicolumn{3}{|c|}{ Left leg } & \multicolumn{6}{|c|}{ Right leg } & \multirow[b]{2}{*}{$\begin{array}{l}\text { Pondl } \\
\text { island }\end{array}$} & \multirow{2}{*}{$\begin{array}{c}\text { Breeding } \\
\text { behavior(s) } \\
\text { observed? }\end{array}$} & \multirow[b]{2}{*}{$\begin{array}{l}\text { Banding } \\
\text { location }\end{array}$} & \multirow[b]{2}{*}{$\begin{array}{l}\text { Banding } \\
\text { year }\end{array}$} & \multirow[b]{2}{*}{$\begin{array}{l}\text { Age at } \\
\text { banding }\end{array}$} \\
\hline & & Top & Middle & Bottom & Top & Middle & Bottom & $\begin{array}{l}\text { Band } \\
\text { color }\end{array}$ & $\begin{array}{l}\text { Code } \\
\text { color }\end{array}$ & $\begin{array}{c}\text { Alpha- } \\
\text { numeric } \\
\text { code }\end{array}$ & & & & & \\
\hline 15 & $\begin{array}{l}2016, \\
2017\end{array}$ & $\begin{array}{c}\text { Dark } \\
\text { blue }\end{array}$ & Red & $\begin{array}{l}\text { Dark } \\
\text { green }\end{array}$ & \begin{tabular}{|l} 
Dark \\
green
\end{tabular} & $\begin{array}{l}\text { Light } \\
\text { blue }\end{array}$ & Metal & - & - & - & SF2/21 & Yes & Brooks Island & 2005 & Chick \\
\hline 16 & $\begin{array}{r}2016, \\
2017\end{array}$ & Orange & $\begin{array}{l}\text { Light } \\
\text { green }\end{array}$ & Metal & - & - & - & Yellow & Black & J731 & SF2/21 & Yes & $\begin{array}{l}\text { Port of } \\
\text { Bellingham }\end{array}$ & 2010 & Chick \\
\hline 17 & 2016 & Orange & $\begin{array}{l}\text { Light } \\
\text { green }\end{array}$ & Metal & - & - & - & Yellow & Black & J520 & SF2/21 & No & $\begin{array}{l}\text { Port of } \\
\text { Bellingham }\end{array}$ & 2010 & Chick \\
\hline 18 & 2016 & White & $\begin{array}{l}\text { Light } \\
\text { blue }\end{array}$ & Metal & - & - & - & Yellow & Black & F108 & SF2/21 & No & Goose Island & 2011 & Chick \\
\hline 19 & $\begin{array}{l}\text { 2016, } \\
2017\end{array}$ & $\begin{array}{c}\text { Dark } \\
\text { blue }\end{array}$ & Orange & Metal & - & - & - & Yellow & Black & E380 & $\begin{array}{c}\text { SF2/17\& } \\
21\end{array}$ & Yes & Eden Landing & 2009 & Chick \\
\hline 20 & $\begin{array}{l}2016, \\
2017\end{array}$ & $\begin{array}{l}\text { Dark } \\
\text { green }\end{array}$ & Yellow & Metal & - & - & - & Yellow & Black & K320 & SF2/21 & Yes & Sheepy Lake & 2012 & Chick \\
\hline 21 & 2016 & Red & Orange & Metal & - & - & - & Yellow & Black & C548 & $\mathrm{SF} 2 / 21$ & Yes & Brooks Island & 2008 & Chick \\
\hline 22 & $\begin{array}{l}2016, \\
2017\end{array}$ & \begin{tabular}{|l} 
Dark \\
blue
\end{tabular} & Orange & Metal & - & - & - & Yellow & Black & E240 & $\begin{array}{c}\text { SF2/17\& } \\
21\end{array}$ & Yes & Brooks Island & 2009 & Adult \\
\hline 23 & 2016 & Red & Orange & Metal & - & - & - & Yellow & Black & C379 & $\mathrm{SF} 2 / 21$ & Yes & Brooks Island & 2008 & Adult \\
\hline 24 & 2016 & White & Yellow & Metal & - & - & - & Yellow & Black & F274 & SF2/17 & No & Sheepy Lake & 2011 & Chick \\
\hline 25 & $\begin{array}{r}2016, \\
2017\end{array}$ & White & $\begin{array}{l}\text { Light } \\
\text { blue }\end{array}$ & Metal & - & - & - & Yellow & Black & F118 & SF2/21 & Yes & Goose Island & 2011 & Chick \\
\hline 26 & $\begin{array}{r}2016, \\
2017\end{array}$ & Red & Orange & Metal & - & - & - & Yellow & Black & C629 & $\begin{array}{c}\text { SF2/17\& } \\
21\end{array}$ & Yes & Brooks Island & 2008 & Chick \\
\hline 27 & $\begin{array}{l}2016, \\
2017\end{array}$ & \begin{tabular}{|l} 
Dark \\
blue
\end{tabular} & $\begin{array}{l}\text { Dark } \\
\text { blue }\end{array}$ & Metal & - & - & - & Yellow & Black & E858 & $\begin{array}{c}\text { SF2/17\& } \\
21\end{array}$ & No & $\begin{array}{l}\text { East Sand } \\
\text { Island }\end{array}$ & 2009 & Chick \\
\hline 28 & 2016 & Red & $\begin{array}{l}\text { Dark } \\
\text { blue }\end{array}$ & Metal & - & - & - & Yellow & Black & C881 & SF2/21 & No & $\begin{array}{l}\text { East Sand } \\
\text { Island }\end{array}$ & 2008 & Chick \\
\hline 29 & $\begin{array}{l}2016, \\
2017\end{array}$ & Red & Orange & Metal & - & - & - & Yellow & Black & C670 & SF2/21 & Yes & Brooks Island & 2008 & Chick \\
\hline 30 & $\begin{array}{r}2016, \\
2017\end{array}$ & $\begin{array}{c}\text { Dark } \\
\text { blue }\end{array}$ & Orange & Metal & - & - & - & Yellow & Black & E399 & SF2/21 & Yes & Brooks Island & 2009 & Chick \\
\hline 31 & 2016 & Orange & White & Metal & - & - & - & Red & White & A123 & SF2/21 & No & $\begin{array}{l}\text { East Sand } \\
\text { Island }\end{array}$ & 2010 & Adult \\
\hline 32 & 2017 & White & White & $\begin{array}{l}\text { Light } \\
\text { Green }\end{array}$ & $\begin{array}{l}\text { Light } \\
\text { green }\end{array}$ & Metal & $\begin{array}{l}\text { Dark } \\
\text { blue } \\
\end{array}$ & - & - & - & SF2/21 & Yes & \begin{tabular}{|c} 
East Sand \\
Island
\end{tabular} & 2003 & Chick \\
\hline
\end{tabular}




\begin{tabular}{|c|c|c|c|c|c|c|c|c|c|c|c|c|c|c|c|}
\hline \multirow[b]{2}{*}{ Tern } & \multirow[b]{2}{*}{ Year(s) } & \multicolumn{3}{|c|}{ Left leg } & \multicolumn{6}{|c|}{ Right leg } & \multirow[b]{2}{*}{$\begin{array}{l}\text { Pond/ } \\
\text { island }\end{array}$} & \multirow{2}{*}{$\begin{array}{c}\text { Breeding } \\
\text { behavior(s) } \\
\text { observed? }\end{array}$} & \multirow[b]{2}{*}{$\begin{array}{l}\text { Banding } \\
\text { location }\end{array}$} & \multirow[b]{2}{*}{$\begin{array}{c}\text { Banding } \\
\text { year }\end{array}$} & \multirow[b]{2}{*}{$\begin{array}{l}\text { Age at } \\
\text { banding }\end{array}$} \\
\hline & & Top & Middle & Bottom & Top & Middle & Bottom & $\begin{array}{l}\text { Band } \\
\text { color }\end{array}$ & $\begin{array}{l}\text { Code } \\
\text { color }\end{array}$ & $\begin{array}{c}\text { Alpha- } \\
\text { numeric } \\
\text { code }\end{array}$ & & & & & \\
\hline 33 & 2017 & $\begin{array}{c}\text { Dark } \\
\text { blue }\end{array}$ & $\begin{array}{l}\text { Dark } \\
\text { blue }\end{array}$ & Yellow & \begin{tabular}{|l} 
Dark \\
green
\end{tabular} & $\begin{array}{l}\text { Light } \\
\text { blue }\end{array}$ & Metal & - & - & - & SF2/21 & Yes & Brooks Island & 2005 & Chick \\
\hline 34 & 2017 & $\begin{array}{c}\text { Dark } \\
\text { blue }\end{array}$ & Orange & $\begin{array}{l}\text { Light } \\
\text { green }\end{array}$ & $\begin{array}{l}\text { Light } \\
\text { green }\end{array}$ & Metal & White & - & - & - & $\begin{array}{l}\mathrm{A} 16 / 11 \\
\text { SF2/21 }\end{array}$ & No & Brooks Island & 2003 & Chick \\
\hline 35 & 2017 & X & Yellow & Red & $\mathrm{X}$ & $\mathrm{X}$ & $\begin{array}{l}\text { Light } \\
\text { green }\end{array}$ & - & - & - & $\begin{array}{r}\mathrm{A} 16 / 11 \\
\mathrm{SF} 2 / 21\end{array}$ & Yes & Unknown & Unknown & Unknown \\
\hline 36 & 2017 & Orange & White & Metal & - & - & - & $X$ & $X$ & $X$ & A16/11 & No & $\begin{array}{l}\text { East Sand } \\
\text { Island }\end{array}$ & $\begin{array}{r}2006 \text { or } \\
2010\end{array}$ & Adult \\
\hline 37 & 2017 & $\begin{array}{l}\text { Dark } \\
\text { blue }\end{array}$ & Orange & Metal & - & - & - & Yellow & $X$ & $\mathrm{X}$ & A16/11 & No & $\begin{array}{l}\text { Brooks Island } \\
\text { or } \\
\text { Eden Landing }\end{array}$ & 2009 & $\begin{array}{r}\text { Adult or } \\
\text { Chick }\end{array}$ \\
\hline 38 & 2017 & White & Orange & Metal & - & - & - & Yellow & Black & $X$ & A16/11 & No & Unknown & Unknown & Unknown \\
\hline 39 & 2017 & Red & $\begin{array}{l}\text { Dark } \\
\text { blue }\end{array}$ & Metal & - & - & - & Red & White & A187 & $\begin{array}{r}\mathrm{A} 16 / 11 \\
\mathrm{SF} 2 / 21\end{array}$ & No & $\begin{array}{c}\text { East Sand } \\
\text { Island }\end{array}$ & 2013 & Chick \\
\hline 40 & 2017 & Orange & $\begin{array}{l}\text { Dark } \\
\text { blue }\end{array}$ & Metal & - & - & - & Yellow & Black & A393 & SF2/21 & Yes & $\begin{array}{l}\text { East Sand } \\
\text { Island }\end{array}$ & 2006 & Chick \\
\hline 41 & 2017 & Red & Orange & Metal & - & - & - & Yellow & Black & C368 & SF2/21 & Yes & Brooks Island & 2008 & Adult \\
\hline 42 & 2017 & Red & Orange & Metal & - & - & - & Yellow & Black & C392 & SF2/21 & No & Brooks Island & 2008 & Adult \\
\hline 43 & 2017 & Red & Orange & Metal & - & - & - & Yellow & Black & C548 & SF2/21 & Yes & Brooks Island & 2008 & Chick \\
\hline 44 & 2017 & Red & Orange & Metal & - & - & - & Yellow & Black & C556 & SF2/21 & Yes & Brooks Island & 2008 & Chick \\
\hline 45 & 2017 & Red & Orange & Metal & - & - & - & Yellow & Black & C615 & A16/11 & Yes & Brooks Island & 2008 & Chick \\
\hline 46 & 2017 & Red & Orange & Metal & - & - & - & Yellow & Black & C617 & SF2/21 & Yes & Brooks Island & 2008 & Chick \\
\hline 47 & 2017 & \begin{tabular}{|l} 
Dark \\
blue
\end{tabular} & Orange & Metal & - & - & - & Yellow & Black & E276 & SF2/21 & No & Brooks Island & 2009 & Adult \\
\hline 48 & 2017 & $\begin{array}{c}\text { Dark } \\
\text { blue }\end{array}$ & Orange & Metal & - & - & - & Yellow & Black & E383 & SF2/21 & Yes & Eden Landing & 2009 & Chick \\
\hline 49 & 2017 & $\begin{array}{c}\text { Dark } \\
\text { blue }\end{array}$ & Orange & Metal & - & - & - & Yellow & Black & E386 & \begin{tabular}{|} 
A16/11, \\
SF2/21
\end{tabular} & No & Eden Landing & 2009 & Chick \\
\hline
\end{tabular}




\begin{tabular}{|c|c|c|c|c|c|c|c|c|c|c|c|c|c|c|c|}
\hline \multirow[b]{2}{*}{ Tern } & \multirow[b]{2}{*}{ Year(s) } & \multicolumn{3}{|c|}{ Left leg } & \multicolumn{6}{|c|}{ Right leg } & \multirow[b]{2}{*}{$\begin{array}{l}\text { Pond/ } \\
\text { island }\end{array}$} & \multirow{2}{*}{$\begin{array}{c}\text { Breeding } \\
\text { behavior(s) } \\
\text { observed? }\end{array}$} & \multirow[b]{2}{*}{$\begin{array}{l}\text { Banding } \\
\text { location }\end{array}$} & \multirow[b]{2}{*}{$\begin{array}{l}\text { Banding } \\
\text { year }\end{array}$} & \multirow[b]{2}{*}{$\begin{array}{c}\text { Age at } \\
\text { banding }\end{array}$} \\
\hline & & Top & Middle & Bottom & Top & Middle & Bottom & $\begin{array}{l}\text { Band } \\
\text { color }\end{array}$ & $\begin{array}{l}\text { Code } \\
\text { color }\end{array}$ & $\begin{array}{c}\text { Alpha- } \\
\text { numeric } \\
\text { code }\end{array}$ & & & & & \\
\hline 50 & 2017 & $\begin{array}{c}\text { Dark } \\
\text { blue }\end{array}$ & Orange & Metal & - & - & - & Yellow & Black & E417 & SF2/21 & Yes & Brooks Island & 2009 & Chick \\
\hline 51 & 2017 & $\begin{array}{l}\text { Dark } \\
\text { green }\end{array}$ & Red & Metal & - & - & - & Yellow & Black & K198 & A16/11 & No & Malheur Lake & 2012 & Chick \\
\hline 52 & 2017 & $\begin{array}{c}\text { Dark } \\
\text { blue }\end{array}$ & Orange & Metal & - & - & - & $\mathrm{X}$ & $\mathrm{X}$ & $\mathrm{X}$ & SF2/21 & No & $\begin{array}{l}\text { Brooks Island } \\
\text { or } \\
\text { Eden Landing }\end{array}$ & 2009 & $\begin{array}{r}\text { Adult or } \\
\text { Chick }\end{array}$ \\
\hline
\end{tabular}



Publishing support provided by the U.S. Geological Survey

Science Publishing Network, Tacoma Publishing Service Center

For more information concerning the research in this report, contact the Director, Western Ecological Research Center

U.S. Geological Survey

3020 State University Drive East

Sacramento, California 95819

https://www.werc.usgs.gov/ 
흐. 